\title{
Native zinc catalyzes selective and traceless release of small molecules in $\beta$-cells
}

Miseon Lee ${ }^{1,2,7}$, Basudeb Maji1 ${ }^{1,2,3,7}$, Debasish Manna ${ }^{1,2,3,7}$, Sevim Kahramann ${ }^{2,6}$, Ruth M. Elgamal ${ }^{1,2,3}$, Jonnell Small ${ }^{1,4}$, Praveen Kokkonda ${ }^{1,2}$, Amedeo Vetere ${ }^{1}$, Jacob M. Goldberg, ${ }^{5}$ Stephen J. Lippard, ${ }^{5}$ Rohit N. Kulkarni ${ }^{2,6}$, Bridget K. Wagner ${ }^{1}$, and Amit Choudhary ${ }^{1,2,3,4, *}$

${ }^{1}$ Chemical Biology and Therapeutics Science, Broad Institute of MIT and Harvard, Cambridge, MA 02142 , USA

2Department of Medicine, Harvard Medical School, Boston, MA 02115, USA

3Divisions of Renal Medicine and Engineering, Brigham and Women's Hospital, Boston, MA 02115, USA

${ }^{4}$ Chemical Biology Program, Harvard University, Cambridge, MA, USA

${ }^{5}$ Department of Chemistry, Massachusetts Institute of Technology, 77 Massachusetts Avenue, Cambridge, Massachusetts 02139, United States

${ }^{6}$ Joslin Diabetes Center, Islet Cell and Regenerative Biology, Boston, MA, USA; Harvard Stem Cell Institute, Boston, MA, USA

${ }^{7}$ These authors contributed equally to this work

*Correspondence: achoudhary@bwh.harvard.edu (A.C.)

*To whom correspondence should be addressed:

\section{Amit Choudhary}

Chemical Biology and Therapeutics Science

Broad Institute of MIT and Harvard

415 Main Street, $\mathrm{Rm} 3012$

Cambridge, MA 02142

Phone: (617) 714-7445

Fax: (617) 715-8969

Email: achoudhary@bwh.harvard.edu 


\section{Table of Contents}

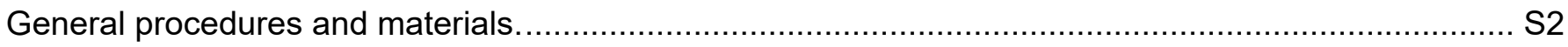

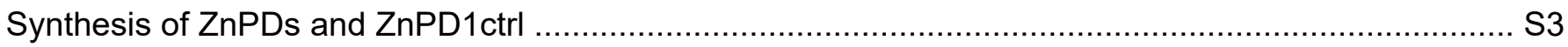

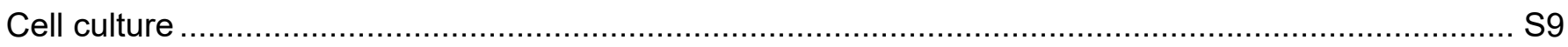

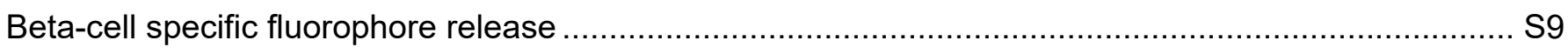

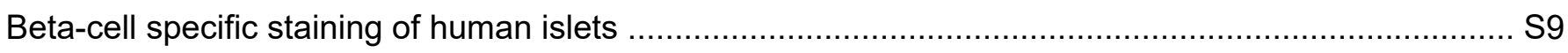

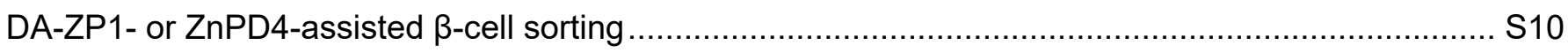

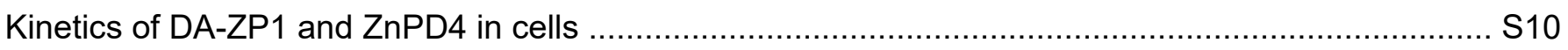

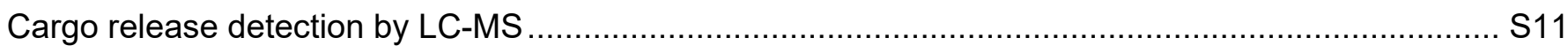

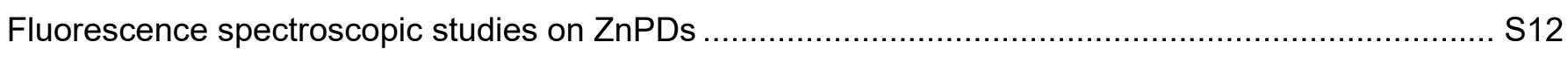

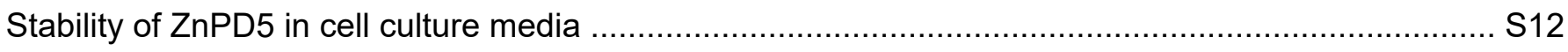

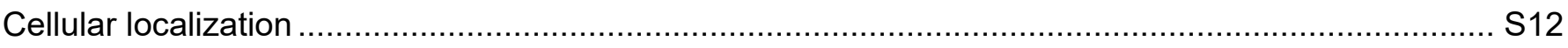

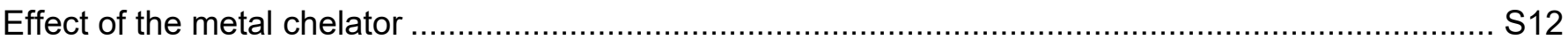

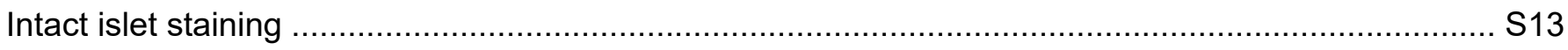

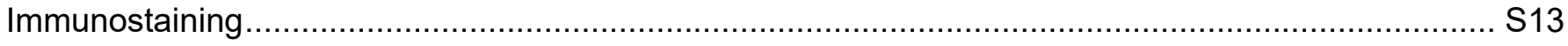

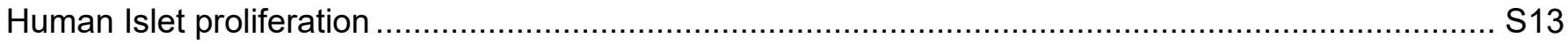

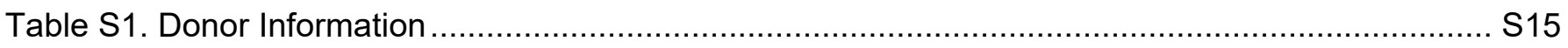

Table S2. Primary antibodies to all antigens and appropriate secondary antibodies........................ S16

Dose and Time dependent of beta-cell specific hydrolysis with DA-ZP1 ................................... S17

Evaluation of the intracellular localization of DA-ZP1 and Zn(II) depletion .................................... S18

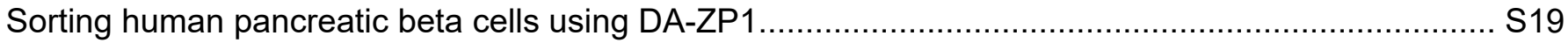

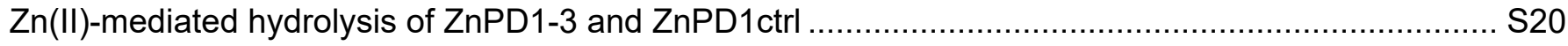

Dose-dependent of beta-cell specific hydrolysis of ZnPD1 ................................................... S20

Dose and Time-dependent of beta-cell specific hydrolysis with ZnPD4 ..................................... S21

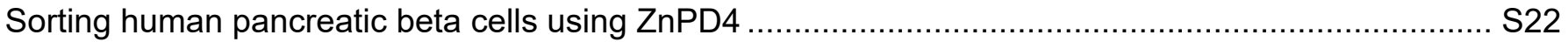

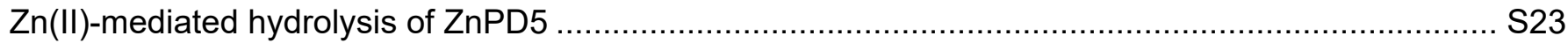

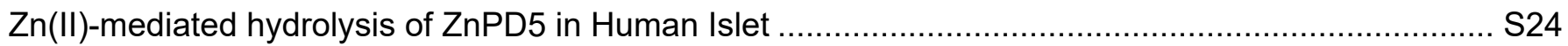

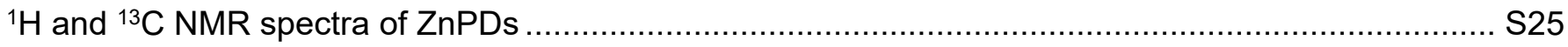

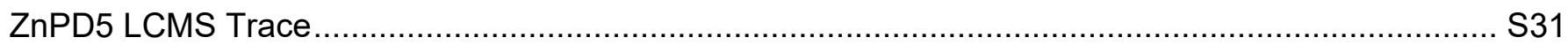




\section{General procedures and materials.}

All reagents were purchased and used as received from commercial sources without further purification. Reactions were performed in round-bottom flasks stirred with Teflon®-coated magnetic stir bars. Moisture and air-sensitive reactions were performed under a dry nitrogen/argon atmosphere. Moisture and airsensitive liquids or solutions were transferred via nitrogen-flushed syringes. As necessary, organic solvents were degassed by bubbling nitrogen/argon through the liquid. The reaction progress was monitored by thin-layer chromatography (TLC) and ultra-performance liquid chromatography mass spectrometry (UPLCMS). Flash column chromatography was performed using silica gel (60 $\AA$ mesh, $20-40 \mu \mathrm{m}$ ) on a Teledyne Isco CombiFlash Rf system. Analytical TLC was performed using Merck Silica gel 60 F254 pre-coated plates $(0.25 \mathrm{~mm})$; illumination at $254 \mathrm{~nm}$ allowed the visualization of UV-active material, and a phosphomolybdic acid (PMA) stain was used to visualize UV-inactive material. UPLC-MS was performed on a Waters ACQUITY UPLC I-Class PLUS System with an ACQUITY SQ Detector 2. Nuclear magnetic resonance (NMR) spectra were recorded on a Bruker 400 Spectrometer $\left({ }^{1} \mathrm{H} \mathrm{NMR}, 400 \mathrm{MHz} ;{ }^{13} \mathrm{C}, 101\right.$ $\mathrm{MHz}$ ) at the Broad Institute of MIT and Harvard. ${ }^{1} \mathrm{H}$ and ${ }^{13} \mathrm{C}$ chemical shifts are indicated in parts per million (ppm) relative to $\mathrm{SiMe}_{4}(\delta=0.00 \mathrm{ppm})$ and internally referenced to residual solvent signals. NMR solvents were purchased from Cambridge Isotope Laboratories, Inc., and NMR data were obtained in $\mathrm{CDCl}_{3}$ or DMSO. Data for ${ }^{1} \mathrm{H}$ NMR are reported as follows: chemical shift value in ppm, multiplicity $(s=$ singlet, $d=$ doublet, $\mathrm{t}=$ triplet, $\mathrm{dd}=$ doublet of doublets, and $\mathrm{m}=$ multiplet), integration value, and coupling constant value in Hz. Tandem liquid chromatography-mass spectrometry (LCMS) was performed on a Waters 2795 separations module with a 3100 mass detector. High-resolution mass spectra were recorded on a JEOL AccuTOF LC-Plus 46 DART system at the department of chemistry instrumentation facility at the Massachusetts Institute of Technology and a Thermo Q Exactive Plus mass spectrometer system equipped with an HESI-II electrospray ionization source at Harvard Center for Mass Spectrometry at the Harvard FAS Division of Science Core Facility. 


\section{Synthesis of ZnPDs and ZnPD1ctrl}

\section{Synthesis of ZnPD1-3}

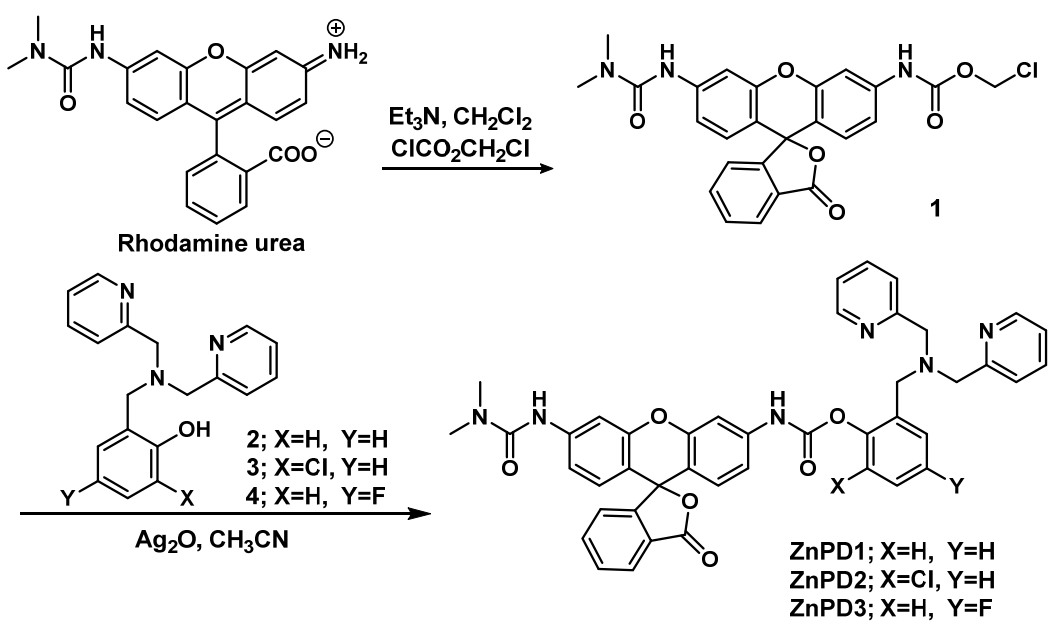

Scheme S1. Synthetic route for ZnPD1-3.

Synthesis of Dimethylurea rhodamine-560 and Zinc-chelating ligand. Dimethylurea rhodamine-560 was prepared as described by Raines et al., and the spectroscopy data matched a literature report (ACS Chem Biol., 2006, 1, 252-260). The zinc-chelating ligands (compound 1) were prepared as described by Nam et al., and the spectroscopy data matched reported values (Chem. Commun., 2012, 48, 5449-5451). Compounds 2 and 3 were made the same way as compound 1.

\section{Synthesis of Compound 1}

Rhodamine urea $(550 \mathrm{mg}, 1.37 \mathrm{mmol})$ was mixed with anhydrous dichloromethane (15 mL, partially soluble) and cooled to $-20^{\circ} \mathrm{C}$. Triethylamine $(208 \mathrm{mg}, 2.05 \mathrm{mmol})$ was added to this solution and stirred at this temperature for $5 \mathrm{~min}$ before adding chloromethyl chloroformate (212 $\mathrm{mg}, 1.64 \mathrm{mmol})$ dropwise. The color changed to dark red immediately. The reaction mixture was stirred at this temperature for 30 min, and the progress of the reaction was monitored by LC-MS. The compound was extracted with dichloromethane, washed with brine, dried over anhydrous $\mathrm{Na}_{2} \mathrm{SO}_{4}$, filtered, and concentrated in vacuo to give a crude residue, which was purified by flash chromatography on silica gel, eluting with $5 \%$ methanol in dichloromethane. The off-white solid product (compound 1,42\%) was obtained after purification and used for the next step to synthesize the ZnPDs. ${ }^{1} \mathrm{H}$ NMR (400 MHz, DMSO- $\left.d_{6}\right) \delta 10.47$ (s, $\left.1 \mathrm{H}\right), 8.59$ (s, $1 \mathrm{H}), 8.01(\mathrm{~d}, J=7.4 \mathrm{~Hz}, 1 \mathrm{H}), 7.79(\mathrm{t}, J=7.2 \mathrm{~Hz}, 1 \mathrm{H}), 7.74(\mathrm{~d}, J=7.2 \mathrm{~Hz}, 1 \mathrm{H}), 7.69(\mathrm{~s}, 1 \mathrm{H}), 7.57(\mathrm{~s}, 1 \mathrm{H})$, 
$7.28(\mathrm{~d}, J=7.4 \mathrm{~Hz}, 1 \mathrm{H}), 7.18(\mathrm{t}, J=6.4 \mathrm{~Hz}, 2 \mathrm{H}), 6.75(\mathrm{~d}, J=8.5 \mathrm{~Hz}, 1 \mathrm{H}), 6.64(\mathrm{~d}, J=8.6 \mathrm{~Hz}, 1 \mathrm{H}), 5.99(\mathrm{~s}$, 2H), $2.94(\mathrm{~s}, 6 \mathrm{H}) .{ }^{13} \mathrm{C}$ NMR (101 MHz, DMSO-d $)$ ס 169.2, 155.8, 153.0, 151.6, 151.4, 151.2, 143.8, 140.8, $136.2,130.7,129.2,128.2,126.3,125.2,124.5,116.1,115.1,114.0,111.7,106.4,106.2,82.6,71.6,36.7$ $(2 \mathrm{C})$.

\section{Synthesis of ZnPD1-3}

Compound 1 (60 mg, $0.121 \mathrm{mmol})$ was placed in a $4 \mathrm{~mL}$ vial and dissolved in anhydrous acetonitrile (2 $\mathrm{mL}$ ). Silver oxide powder (28.1 mg, 1.0 equiv.) was added followed by the corresponding $\mathrm{Zn}$ chelating group (compound 2-4, 1.1 equiv.) at room temperature. The resulting reaction mixture was stirred for $3 \mathrm{~h}$ at this temperature. The progress of the reaction was monitored by LCMS. The solvent was removed and the crude product was purified by flash chromatography on silica gel, eluting with $5 \%$ methanol in dichloromethane to produce a solid white compound.

ZnPD1 (14\% yield): ${ }^{1} \mathrm{H}$ NMR (400 MHz, $\left.\mathrm{CDCl}_{3}\right) \delta 9.99$ (br, 1H), 8.52 (ddd, $\left.J=5.0,1.8,0.9 \mathrm{~Hz}, 2 \mathrm{H}\right), 8.23$ (br, 1H), $8.01(\mathrm{dt}, J=7.4,1.0 \mathrm{~Hz}, 1 \mathrm{H}), 7.67(\mathrm{td}, J=7.4,1.3 \mathrm{~Hz}, 1 \mathrm{H}), 7.64-7.53(\mathrm{~m}, 4 \mathrm{H}), 7.45(\mathrm{~m}, 3 \mathrm{H})$, $7.37-7.27(\mathrm{~m}, 2 \mathrm{H}), 7.22-7.10(\mathrm{~m}, 6 \mathrm{H}), 7.00(\mathrm{dd}, J=8.6,2.1 \mathrm{~Hz}, 1 \mathrm{H}), 6.77-6.61(\mathrm{~m}, 3 \mathrm{H}), 3.97(\mathrm{~s}, 4 \mathrm{H})$, $3.82(\mathrm{~s}, 2 \mathrm{H}), 3.03(\mathrm{~s}, 6 \mathrm{H}) .{ }^{13} \mathrm{C}$ NMR $\left(101 \mathrm{MHz}, \mathrm{CDCl}_{3}\right) \delta 169.8,164.5,157.0,155.6(2 \mathrm{C}), 153.4,152.1$, $152.0,149.9,147.5(2 \mathrm{C}), 141.7,141.1,138.4(2 \mathrm{C}), 135.3,131.8,129.9,129.3,129.0,128.7,128.5,126.7$, $125.9,125.2,124.7(2 \mathrm{C}), 124.1,123.3,123.2(2 \mathrm{C}), 115.6,114.6,113.6,113.1,107.5,106.6,83.2,59.3(2 \mathrm{C})$, 55.0, 36.7(2C). HRMS (Dart-TOF) (m/z): [M+H] $]^{+}$calculated for $\mathrm{C}_{43} \mathrm{H}_{37} \mathrm{~N}_{6} \mathrm{O}_{6}, 733.2775$; found, 733.2769.

ZnPD2: The NMR spectrum was not obtained due to the instability of the compound. The compound decomposed in the NMR tube while attempting to obtain the spectrum.

ZnPD3 (11\% yield): ${ }^{1} \mathrm{H}$ NMR (400 MHz, $\left.\mathrm{CDCl}_{3}\right) \delta 10.41(\mathrm{~s}, 1 \mathrm{H}), 8.51(\mathrm{~d}, J=4.9 \mathrm{~Hz}, 2 \mathrm{H}), 8.00(\mathrm{~d}, J=7.5$ $\mathrm{Hz}, 1 \mathrm{H}), 7.66(\mathrm{t}, J=7.4 \mathrm{~Hz}, 1 \mathrm{H}), 7.60(\mathrm{t}, J=7.4 \mathrm{~Hz}, 1 \mathrm{H}), 7.57-7.43(\mathrm{~m}, 4 \mathrm{H}), 7.33(\mathrm{~d}, J=7.8 \mathrm{~Hz}, 2 \mathrm{H})$, $7.19-6.92(\mathrm{~m}, 7 \mathrm{H}), 6.76(\mathrm{~s}, 1 \mathrm{H}), 6.66(\mathrm{t}, \mathrm{J}=9.1 \mathrm{~Hz}, 2 \mathrm{H}), 3.80(\mathrm{~s}, 4 \mathrm{H}), 3.65(\mathrm{~s}, 2 \mathrm{H}), 3.02(\mathrm{~s}, 6 \mathrm{H}) .{ }^{13} \mathrm{C}$ NMR $\left(101 \mathrm{MHz}, \mathrm{CDCl}_{3}\right) \delta 169.8,159.8(\mathrm{~J}=245 \mathrm{~Hz}), 158.1,157.9,155.5,153.4,152.4,152.0,151.9(\mathrm{~J}=9.5$ $\mathrm{Hz}), 149.1,148.7,145.9$ (2C), 145.8, 141.8, 141.2, 137.4, 137.0, 135.2, 129.9, $128.4(\mathrm{~J}=20.5 \mathrm{~Hz}), 126.6$, 125.1, 125.0, $124.8(\mathrm{~J}=8.4 \mathrm{~Hz}), 124.3,124.1,123.4,122.8,122.5,118.0,115.5,115.2,114.7,113.6$, 
112.9, 107.4, 106.7, 83.2, 59.09, 55.29, 36.7 (2C). HRMS (Dart-TOF) (m/z): $[\mathrm{M}+\mathrm{H}]^{+}$calculated for $\mathrm{C}_{43} \mathrm{H}_{36} \mathrm{~N}_{6} \mathrm{O}_{6} \mathrm{~F}, 751.2680$; found, 751.2675.

\section{Synthesis of ZnPD1ctrl}

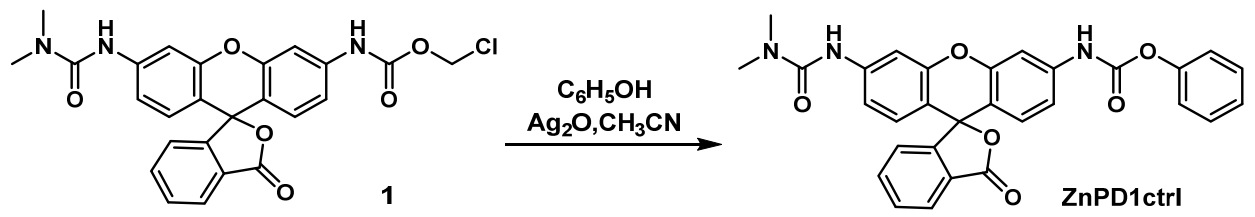

Scheme S2. Synthetic route for ZnPD1ctrl.

ZnPD1ctrl (30\% yield) was synthesized by following a method similar to that used for ZnPD1. ${ }^{1} \mathrm{H}$ NMR (400 MHz, DMSO-d $) \delta 10.54(\mathrm{~s}, 1 \mathrm{H}), 8.59(\mathrm{~s}, 1 \mathrm{H}), 8.02(\mathrm{dt}, J=7.5,1.0 \mathrm{~Hz}, 1 \mathrm{H}), 7.80(\mathrm{dt}, J=7.5,1.2 \mathrm{~Hz}$, 1H), $7.73(\mathrm{dt}, J=7.5,1.0 \mathrm{~Hz}, 1 \mathrm{H}), 7.68(\mathrm{~d}, J=2.1 \mathrm{~Hz}, 1 \mathrm{H}), 7.60(\mathrm{~d}, J=2.1 \mathrm{~Hz}, 1 \mathrm{H}), 7.47-7.40(\mathrm{~m}, 2 \mathrm{H})$, $7.30-7.23(\mathrm{~m}, 4 \mathrm{H}), 7.20(\mathrm{ddd}, J=8.8,7.4,2.2 \mathrm{~Hz}, 2 \mathrm{H}), 6.75(\mathrm{~d}, J=8.7 \mathrm{~Hz}, 1 \mathrm{H}), 6.64(\mathrm{~d}, J=8.7 \mathrm{~Hz}, 1 \mathrm{H})$, 2.93 (s, 6H). ${ }^{13} \mathrm{C}$ NMR (101 MHz, DMSO-d $) \delta$ 168.7, 155.3, 152.7, 151.6, 151.1, 150.7, 150.3, 143.2, $140.9,135.7,130.2,129.5(2 \mathrm{C}), 128.7,127.7,125.8,125.6,124.7,124.0,121.9(2 \mathrm{C}), 115.6,114.6,113.1$, 111.2, 105.9, 105.6, 82.2, 54.9, 36.2. HRMS (Dart-TOF) $(\mathrm{m} / \mathrm{z}):[\mathrm{M}+\mathrm{H}]^{+}$calculated for $\mathrm{C}_{30} \mathrm{H}_{24} \mathrm{~N}_{3} \mathrm{O}_{6}$, 522.1665; found, 522.1660.

\section{Synthesis of ZnPD4}
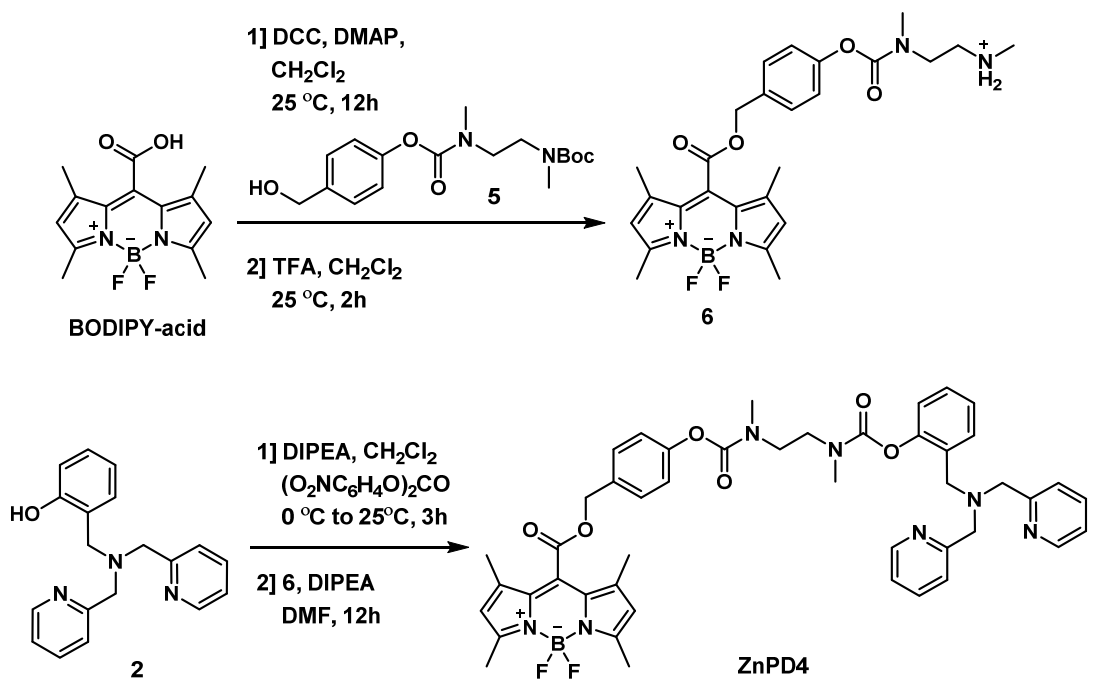

Scheme S3. Synthetic route for ZnPD4. 
Synthesis of BODIPY-acid and linker 5. B-COOH-G was prepared as described by Changhua et al., and the spectroscopy data matched those previously reported (J. Am. Chem. Soc. 2017, 139, 10157-10163). The linker was prepared as described by Gillies et al., and the spectroscopy data matched literature values (J. Am. Chem. Soc. 2009, 131, 18327-18334).

\section{Synthesis of ZnPD4.}

Linker $5(500 \mathrm{mg}, 1.48 \mathrm{mmol})$ was dissolved in anhydrous dichloromethane $(7.4 \mathrm{~mL})$ followed by the addition of 4-dimethylaminopyridine $(18 \mathrm{mg}, \quad 0.15 \mathrm{mmol}), \quad \mathrm{N}, \mathrm{N}^{\prime}$-dicyclohexylcarbodiimide $\quad(457 \mathrm{mg}$, $2.22 \mathrm{mmol})$, and BODIPY-acid (625 mg, $2.22 \mathrm{mmol})$. The reaction was stirred at room temperature for 12 $\mathrm{h}$ until the starting material was completely consumed. The reaction mixture was then diluted with dichloromethane, quenched with an aqueous solution of saturated $\mathrm{NaHCO}_{3}$, and extracted with dichloromethane. The organic layers were combined, washed with brine, dried over anhydrous $\mathrm{Na}_{2} \mathrm{SO}_{4}$, filtered, and concentrated in vacuo to give a crude residue, which was purified by flash column chromatography on silica gel, eluting with $5 \%$ methanol in dichloromethane. The orange foam product (compound 8) was obtained and carried forward to the next step. The ester $(200 \mathrm{mg}, 0.33 \mathrm{mmol})$ was dissolved in anhydrous dichloromethane $(3.25 \mathrm{~mL}, 0.1 \mathrm{M})$ and then trifluoroacetic acid (370 mg, $3.25 \mathrm{mmol}$ ) was added to the reaction mixture. The solution was stirred for $2 \mathrm{~h}$. The solvent was removed in vacuo, and dichloromethane was successively added and evaporated to remove residual trifluoroacetic acid and to provide the deprotected product. This product was carried over to the next step without further purification, wherein 4-nitrophenyl carbonate $(119 \mathrm{mg}, 0.39 \mathrm{mmol})$ and $\mathrm{N}, \mathrm{N}$-diisopropylethylamine $(63 \mathrm{mg}$, $0.49 \mathrm{mmol})$ were added to the solution of zinc chelating ligand $(99.3 \mathrm{mg}, 0.33 \mathrm{mmol})$ in dichloromethane $(3.25 \mathrm{~mL})$ at $0^{\circ} \mathrm{C}$. The reaction mixture was slowly warmed up to room temperature over $3 \mathrm{~h}$. N,Ndiisopropylethylamine $(168 \mathrm{mg}, 1.30 \mathrm{mmol})$ and trifluoroacetic acid salt of compound $8(0.33 \mathrm{mmol})$ in dimethylformamide were added to the reaction mixture and stirred for $12 \mathrm{~h}$. The solvent was removed in vacuo, and the residue was purified by flash column chromatography eluting with $10 \%$ methanol in dichloromethane to give the pure fraction of ZnPD4 as a dark red solid (11\% yield). ${ }^{1} \mathrm{H} \mathrm{NMR}(400 \mathrm{MHz}$, $\left.\mathrm{CDCl}_{3}\right) \delta 8.54-8.43(\mathrm{~m}, 2 \mathrm{H}), 7.73-7.58(\mathrm{~m}, 3 \mathrm{H}), 7.53(\mathrm{~d}, J=8.0 \mathrm{~Hz}, 2 \mathrm{H}), 7.48-7.34(\mathrm{~m}, 2 \mathrm{H}), 7.21-$ 
$7.09(\mathrm{~m}, 6 \mathrm{H}), 6.99(\mathrm{~m}, 1 \mathrm{H}), 6.02(\mathrm{~s}, 2 \mathrm{H}), 5.36-5.33(\mathrm{~m}, 2 \mathrm{H}), 3.85-3.74(\mathrm{~m}, 4 \mathrm{H}), 3.74-3.53(\mathrm{~m}, 6 \mathrm{H})$, $3.21-3.10(\mathrm{~m}, 3 \mathrm{H}), 3.06(\mathrm{~s}, 3 \mathrm{H}), 2.51(\mathrm{~s}, 6 \mathrm{H}), 2.00(\mathrm{~s}, 6 \mathrm{H}) \cdot{ }^{13} \mathrm{C} \mathrm{NMR}\left(101 \mathrm{MHz}, \mathrm{CDCl}_{3}\right) \delta$ 165.1, 159.7, $157.8,155.0,154.9,154.6,152.1,151.9,150.1,149.9(2 \mathrm{C}), 141.3,136.6(2 \mathrm{C}), 131.5,131.3,130.8,130.2$, 128.1, 126.0, 125.9, 125.8, $122.9(2 \mathrm{C}), 122.6,122.5,122.3(2 \mathrm{C}), 122.1(2 \mathrm{C}), 121.3(2 \mathrm{C}), 68.1,60.4,53.6$, 52.6, 52.4, 47.7, 47.0, 46.8, 35.6, 35.4, 14.9 (2C), 12.9 (2C). HRMS (Dart-TOF) (m/z): [M+H] calculated for $\mathrm{C}_{46} \mathrm{H}_{49} \mathrm{BF}_{2} \mathrm{~N}_{7} \mathrm{O}_{6}, 844.3805$; found, 844.3840.

\section{Synthesis of ZnPD5}
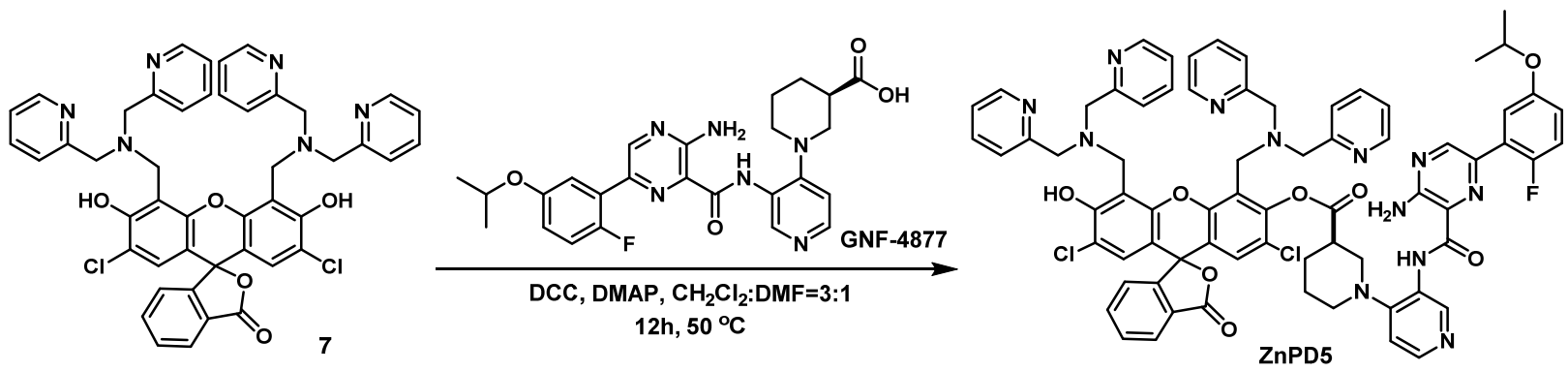

Scheme S4. Synthetic route for ZnPD5.

Synthesis of Zinpyr-1 (7) and GNF-4877. Compound 7 was prepared as described by Burdette et al., and the spectroscopy matched literature reports (J. Am. Chem. Soc. 2001, 123, 7831-7841). GNF-4877 was prepared as described by Shen et al., and the spectroscopy data agreed with previous reports (Nat. Commun. 2015, 6, 8372).

\section{Synthesis of ZnPD5}

To a mixture of compound 7 (332.8 $\mathrm{mg}, 0.40 \mathrm{mmol})$ and GNF-4877 (100 mg, $0.20 \mathrm{mmol})$ in anhydrous dichloromethane $(2.02 \mathrm{ml})$ and dimethylformamide $(1.01 \mathrm{~mL})$ was added $N, N^{\prime}$-dicyclohexylcarbodiimide (62.5 $\mathrm{mg}, 0.3 \mathrm{mmol})$ and 4-dimethylaminopyridine $(12.3 \mathrm{mg}, 0.1 \mathrm{mmol})$. The reaction mixture was stirred for 12 hours at $50{ }^{\circ} \mathrm{C}$. After evaporation of the solvent under reduced pressure the crude residue was chromatographed on silica gel with $10 \%$ methanol in dichloromethane to give the ester ZnPD5 (40 mg, $15.2 \%)$ as a pale pink solid. ${ }^{1} \mathrm{H}$ NMR $(400 \mathrm{MHz}$, DMSO-d, $330 \mathrm{~K}) \delta 10.31(\mathrm{~s}, 1 \mathrm{H}), 9.32(\mathrm{~s}, 1 \mathrm{H}), 8.63(\mathrm{~d}, J$ $=2.1 \mathrm{~Hz}, 1 \mathrm{H}), 8.51(\mathrm{~d}, J=4.9,2 \mathrm{H}), 8.32(\mathrm{~d}, J=5.4 \mathrm{~Hz}, 3 \mathrm{H}), 8.00(\mathrm{~d}, J=7.6,1 \mathrm{H}), 7.83(\mathrm{t}, J=7.5 \mathrm{~Hz}, 1 \mathrm{H})$, 
$7.79-7.66(\mathrm{~m}, 5 \mathrm{H}), 7.49(\mathrm{t}, J=7.0 \mathrm{~Hz}, 2 \mathrm{H}), 7.42$ (ddd, $J=6.5,3.1,1.3 \mathrm{~Hz}, 2 \mathrm{H}), 7.33(\mathrm{~d}, J=7.8 \mathrm{~Hz}, 2 \mathrm{H})$, $7.29-7.24(\mathrm{~m}, 3 \mathrm{H}), 7.24-7.14(\mathrm{~m}, 4 \mathrm{H}), 7.10-7.03(\mathrm{~m}, 2 \mathrm{H}), 6.99(\mathrm{dt}, J=9.1,3.5 \mathrm{~Hz}, 1 \mathrm{H}), 6.69(\mathrm{~d}, J=$ $2.2 \mathrm{~Hz}, 1 \mathrm{H}), 6.56(\mathrm{~s}, 1 \mathrm{H}), 4.58$ (septet, $J=6.0,0.9 \mathrm{~Hz}, 1 \mathrm{H}), 4.15(\mathrm{~s}, 2 \mathrm{H}), 4.08-3.83(\mathrm{~m}, 6 \mathrm{H}), 3.75(\mathrm{~s}, 4 \mathrm{H})$, $3.49(\mathrm{~d}, \mathrm{~J}=10.4 \mathrm{~Hz}, 1 \mathrm{H}), 3.25$ (buried in the signal of $\left.\mathrm{H}_{2} \mathrm{O}, 1 \mathrm{H}\right) 2.97(\mathrm{t}, J=12.8 \mathrm{~Hz}, 1 \mathrm{H}), 2.92-2.75(\mathrm{~m}$, 2H), $2.01(\mathrm{br}, 1 \mathrm{H}), 1.82(\mathrm{br}, 2 \mathrm{H}), 1.57(\mathrm{br}, 1 \mathrm{H}), 1.23(\mathrm{~d}, J=6.0 \mathrm{~Hz}, 6 \mathrm{H}) .{ }^{13} \mathrm{C}$ NMR $(101 \mathrm{MHz}$, DMSO-d 298K) $\delta 169.8,168.0,163.5,157.9$ (2C), 157.2 (2C), 155.7, 154.3, 153.9, 153.6 (J= $239 \mathrm{~Hz}), 151.0$, 149.5, $148.8(2 \mathrm{C}), 148.5,147.9(\mathrm{~J}=9.6 \mathrm{~Hz}), 147.8,147.7,146.9,146.2,142.2,137.1(2 \mathrm{C}), 135.9(2 \mathrm{C})$, 135.8, $135.0(J=3.4 \mathrm{~Hz}), 130.7,128.2,126.9,126.4,125.7,125.3,124.6(J=14 \mathrm{~Hz}), 123.9,123.5,123.1$ (2C), $122.8(2 \mathrm{C}), 122.6(2 \mathrm{C}), 122.1,122.0(2 \mathrm{C}), 121.3,117.8,117.2,116.8(\mathrm{~J}=24.0 \mathrm{~Hz}), 116.6,115.9(\mathrm{~J}=$ $6 \mathrm{~Hz})), 115.1$, 112.0, 109.3, 81.2, 69.8, 59.5, 59.0, 58.6, 52.5, 50.2, 48.9, 48.6, 41.6, 26.5, 24.4, 21.7, 21.6. HRMS (Dart-TOF) (m/z): [M+H] $]^{+}$calculated for $\mathrm{C}_{71} \mathrm{H}_{62} \mathrm{C}_{12} \mathrm{FN}_{12} \mathrm{O}_{8}, 1299.4175$; found, 1299.4169 . 


\section{Cell culture}

All cells were cultured in a humidified $5 \% \mathrm{CO}_{2}$ atmosphere at $37{ }^{\circ} \mathrm{C}$. HEK293T (ATCC) and PANC-1 (ATCC) were cultured in Dulbecco's Modified Eagle's Medium (Life Technologies) supplemented with 10\% fetal bovine serum (FBS; Life Technologies) and 1x penicillin/streptomycin (Life Technologies). INS-1E cells were cultured in RPMI 1640 medium (Life Technologies) supplemented with 10\% FBS, 1x penicillin/streptomycin, $1 \mathrm{mM}$ sodium pyruvate (Life Technologies), and 3.5 $\mu \mathrm{L} / \mathrm{L}$ BME (Sigma). Alpha TC1 clone 6 cells were cultured in Dulbecco's Modified Eagle's Medium, low glucose (Gibco Cat. No. 11885084) medium supplemented with $10 \%$ HyClone FBS and $1 \times$ penicillin/streptomycin. Human islet cells were maintained in CMRL 1066 (Life Technologies) containing 10\% FBS, 1× penicillin/streptomycin, and 2 mM L-glutamine. Cells were continuously maintained at $<90 \%$ confluency. All cell lines were sourced commercially or were functionally validated. Cells were periodically tested for mycoplasma contamination using the MycoAlert PLUS Mycoplasma Detection Kit (Lonza).

\section{Beta-cell specific fluorophore release}

In a 96-well plate, INS-1E (30,000 cells), HEK293T (12,000 cells), alpha TC1 clone 6 (30,000 cells), and PANC-1 (20,000 cells) were plated per well and cultured for $24 \mathrm{~h}$ at $37^{\circ} \mathrm{C}$ with $5 \% \mathrm{CO}_{2}$. Compounds (DAZP1, DA-FC, ZnPD1, ZnPD4, ZnPD5, and ZnPD1ctrl) at the indicated concentration in the corresponding cell culture medium containing $2 \times$ DAPI were incubated for $1 \mathrm{~h}$ inside the incubator. The medium containing compound was removed and washed with $3 \times 100 \mu \mathrm{L}$ of fresh medium, and finally, another $100 \mu \mathrm{L}$ of fresh, dye-free medium was added. The cells were immediately imaged using a high-content fluorescence microscope (Molecular Devices or Operetta Phenix) in both the DAPI and FITC channels at 20X magnification. Images were analyzed using the MetaXpress or Harmony software and data were plotted using GraphPad Prism 6.

\section{Beta-cell specific staining of human islets}

Approximately 30,000 freshly dissociated human islet cells per well were plated in a 96-well format and incubated for $24 \mathrm{~h}$ at $37{ }^{\circ} \mathrm{C}$ with $5 \% \mathrm{CO}_{2}$. Cells were incubated with DA-ZP1 $(5 \mu \mathrm{M})$ at the indicated 
concentration in the human islet cell culture medium for $1 \mathrm{~h}$ in the incubator. Cells were then washed with $2 \times 100 \mu \mathrm{L}$ of fresh medium before fixing and permeabilizing with cold methanol for $1-2$ min following a literature protocol (Jamur et al., 2010). Cells were then immunostained with rat anti-C-Peptide antibody (Cell Signaling) overnight at $4{ }^{\circ} \mathrm{C}$ and subsequently stained with Alexa Fluor 647 anti-rat (ThermoFisher) and $1 \times$ DAPI (ThermoFisher) for $1 \mathrm{~h}$. The plates were imaged using the Phenix high-content confocal microscope (Perkin Elmer) with DAPI as the nuclear counterstain.

\section{DA-ZP1- or ZnPD4-assisted $\beta$-cell sorting}

Upon receipt, islets were centrifuged at $1000 \mathrm{rpm}$ for $1 \mathrm{~min}$ and resuspended in supplemented CMRL 1066 medium. Islets were then transferred to $10 \mathrm{~cm}$ culture dishes and cultured overnight to $24 \mathrm{~h}$. Healthy islets were handpicked and washed with DPBS. For DA-ZP1 or ZnPD4 staining, islets were dissociated into single cells by TrypLE. Briefly, $1 \mathrm{~mL}$ TrypLE was added to human islet pellet and incubated at $37^{\circ} \mathrm{C}$ for 12 min by mixing the tube every 3-4 min. At the end of incubation, TrypLE was neutralized by adding $9 \mathrm{~mL}$ DMEM HG containing 10\% FBS. The cell suspension was filtered using a $30 \mu \mathrm{m}$ filter to remove any aggregates, counted on a hemocytometer, and pelleted by spinning cells at $1200 \mathrm{rpm}$ for $5 \mathrm{~min}$. Cells were washed with CMRL 1066 final wash/culture medium and resuspended in the final wash/culture medium with DA-ZP1 or ZnPD4 $(160 \mathrm{nM})$ for $30 \mathrm{~min}$ at $37^{\circ} \mathrm{C}$. At the end of the incubation period, cells were washed and the cell pellet was resuspended in the final wash/culture medium. DA-ZP1 or ZnPD4 positive and negative cells were sorted by FACSAria cell sorter (BD Biosciences, Joslin Flow Cytometry Core). Sorted cells were spun at $1200 \mathrm{rpm}$ for $5 \mathrm{~min}$ and washed with DPBS, then fixed in $4 \%$ PFA for $15 \mathrm{~min}$ at room temperature. Cells were washed and embedded in agarose and paraffin, sectioned and used for immunostaining as previously described by El Ouaamari et al., (Cell Metab. 2016, 23, 194-205). Analysis of flow cytometry data was completed using FlowJo 10.4.2 (FlowJo LLC, Ashland, OR). The gating strategy is shown in Figures S3 and S7. The donor demographic information is summarized in Table S1.

\section{Kinetics of DA-ZP1 and ZnPD4 in cells}

The cells were plated in black-walled, clear-bottom 96-well plates coated with poly-D-lysine (PDL, Sigma Aldrich) for $1 \mathrm{~h}$ and washed with $200 \mu \mathrm{L}$ of PBS/well. INS-1E and $\alpha \mathrm{TC}-1.6$ cells were plated at 30,000 
cells/well, and PANC-1 and HEK293T cells were plated at 11,250 cells/well. After plating, the cells were incubated overnight at $37^{\circ} \mathrm{C}$. DAZP1 or ZnPD4 solutions were prepared in microcentrifuge tubes using the respective, dye-free cell mediums: RPMI 1640, DMEM + GlutaMAX, or DMEM (low glucose). The

medium in the 96-well plates was removed by gently inverting the plates upside down. Any medium remaining in the wells was not removed. DAZP1 or ZnPD4 solutions (10 $\mu \mathrm{M}-10 \mathrm{nM})$ in dye-free medium were added to the wells (100 $\mu \mathrm{L} /$ well). After the solutions were added, the plates were incubated for $1-25$ $\mathrm{h}$ at $37^{\circ} \mathrm{C}$, after which time the plates were gently inverted to remove the medium. Any residual medium was removed with a multichannel pipette. The wells were then gently washed twice with reconstituted dyefree cell medium (100 $\mu \mathrm{L} /$ well). DAPI was then added to the wells in dye-free cell medium (100 $\mu \mathrm{L} /$ well), and the plates were incubated at $37^{\circ} \mathrm{C}$ for $30 \mathrm{~min}$. DAPI was removed by gently inverting the plates, and the residual medium was removed with a multichannel pipette. The wells were washed with $50 \mu \mathrm{L} /$ well of dye-free INS-1E/PANC-1 medium. Finally, $100 \mu \mathrm{L} /$ well of dye-free cell medium was added to wells, and the plates were sealed for live-cell imaging.

\section{Cargo release detection by LC-MS}

Samples of $1 \times 10^{6}$ cells were treated with compound $(5 \mu \mathrm{M})$ in a 6 -well plate for the indicated duration before collecting by treatment with trypsin. Cells were re-suspended in $1 \mathrm{~mL}$ PBS and pelleted down at $4000 \times g$ for 2 min. The supernatant was removed carefully keeping the residual PBS along with the cell pellet. Cells were briefly vortexed and $10 \mu \mathrm{L}$ DMSO was added before vortexing vigorously for $15 \mathrm{~s}$. The cell suspension was flash-frozen in liquid nitrogen followed by thawing and vortexing for $15 \mathrm{~s}$. This process was repeated twice. A $50-\mu \mathrm{L}$ aliquot of acetonitrile containing $2 \mu \mathrm{M}$ spautin as an internal standard was added and the mixture was vortexed for $30 \mathrm{~s}$. The suspension was centrifuged at $10000 \times \mathrm{g}$ for $1 \mathrm{~min}$ and then the supernatant was collected for mass spectrometric analysis. 


\section{Fluorescence spectroscopic studies on ZnPDs}

The compound in PBS was taken in a 96-well microplate $(250 \mu \mathrm{L}, 10 \mu \mathrm{M}$ per well, Nunc 96 Well Plates) and incubated with different concentrations of $\mathrm{ZnSO}_{4}(0-1 \mathrm{mM})$. Reaction kinetics were monitored by measuring the fluorescence of the activated fluorescein dye $\left(\lambda_{\mathrm{ex}}=490 \mathrm{~nm}, \lambda_{\mathrm{em}}=522 \mathrm{~nm}\right)$ over $20 \mathrm{~h}$.

\section{Stability of ZnPD5 in cell culture media}

Samples of the compound in INS-1E and human islet media (250 $\mu \mathrm{L}, 10 \mu \mathrm{M}$ per well) alone or in the presence of varying concentrations of $\mathrm{ZnSO}_{4}(125-1000 \mu \mathrm{M})$ were incubated and the stability was monitored by measuring the fluorescence signal $\left(\lambda_{\mathrm{ex}}=490 \mathrm{~nm}, \lambda_{\mathrm{em}}=522 \mathrm{~nm}\right)$ for over $12 \mathrm{~h}$.

\section{Cellular localization}

Localization of DA-ZP1 release was performed following a reported cell-painting method (Nat. Protoc. 2016, 11, 1757). In a typical experimental procedure, INS-1E cells were treated with $5 \mu \mathrm{M}$ DA-ZP1 for $1 \mathrm{~h}$ in a 96-well plate. The media was removed and $60 \mu \mathrm{L} /$ well MitoTracker (Invitrogen, cat. no. M22426) solution containing $2 \times$ DAPI was added and incubated for $30 \mathrm{~min}$ in the dark. To the same well, $20 \mu \mathrm{L} 16 \%$ PFA was added and incubated for an additional 20 min in dark. Cells were then washed twice with $100 \mu \mathrm{L}$ HBSS and then processed for imaging. The cells were imaged by confocal microscopy using DAPI, FITC, and deep red $(647 \mathrm{~nm})$ channels.

\section{Effect of the metal chelator}

INS-1E cells were first incubated in media containing either DMSO or $25 \mu \mathrm{M}$ TPEN for 30 min followed incubating with DA-ZP1 $(5 \mu \mathrm{M})$ or treated with $4 \%$ PFA for fixation. DA-ZP1 treated live cells were processed for imaging after $30 \mathrm{~min}$ of incubation. The fixed cells were incubated with ZnPD5 (5 $\mu$ M) in PBS containing $1 \times$ DAPI for $3 \mathrm{~h}$. Cells were then imaged under a fluorescence microscope using DAPI and FITC channels. 


\section{Intact islet staining}

Intact islet cells were pipetted up and down 5-7 times in culture media using $1 \mathrm{~mL}$ tips and then portioned (60-80 islets per condition) into $1 \mathrm{~mL}$ microtubes. Islets were incubated with ZnPD5 at $5 \mu \mathrm{M}$ for $3 \mathrm{~h}$ inside the incubator with occasional mixing. Cells were then spun down (200 RCF, 2 min) and the supernatant was carefully removed. $300 \mu \mathrm{L}$ of TrypLE was added to each tube and incubated at $37^{\circ} \mathrm{C}$ for 12 min with occasional mixing. Culture media $(700 \mu \mathrm{L})$ was added to each tube and pipetted up and down 7-10 times using a $1 \mathrm{~mL}$ pipet. Cells were then spun down at $200 \mathrm{RCF}$ for $5 \mathrm{~min}$ and the supernatant was carefully removed. Cells were then resuspended in $300 \mu \mathrm{L}$ media and transferred to a pre-coated 96-well plate in two replicates. Cells were allowed to adhere by culturing for $12 \mathrm{~h}$ and then fixed with $4 \%$ PFA for 20 min and subsequently permeabilized with $0.2 \%$ Triton- $X$ for $20 \mathrm{~min}$. Cells were then processed for primary and secondary antibody staining following the protocol as discussed earlier. Cells were imaged by using fluorescence microscopy under DAPI, FITC, and $647 \mathrm{~nm}$ channels.

\section{Immunostaining}

Sections of agar and paraffin-embedded cells were stained as previously described (J. Diabetes Res. 2015, 2015, 450128). Primary antibodies to all antigens and appropriate secondary antibodies with their working dilutions are listed in Table S2. Digital images were taken with an AXIO Imager A2 upright microscope equipped with an X-Cite series 120Q light source, Axiocam 512 color camera, and Zen 2.3 lite software. Images were overlaid and hormone-positive cells counted using ImageJ software. $\geq 5,000$ cells were counted per group ( $\mathrm{n}=3$ replicate slides).

\section{Human Islet proliferation}

Human islets were dissociated into a single cell suspension using TrypLE and plated at 10,000 islet cells per well in coated 384-well plates. Islet cells were cultured in FBS-supplemented CMRL 1066 medium with $10 \mu \mathrm{M}$ 5-ethynyl-2'-deoxyuridine (EdU) and incubated at $37^{\circ} \mathrm{C}$ with $5 \% \mathrm{CO}_{2}$. Every 2 days, cells were treated with DMSO and ZnPD5 in duplicate at doses ranging from $312.5 \mathrm{nM}$ to $2.5 \mu \mathrm{M}$. After 6 days, cells were fixed using 3.7\% PFA, permeabilized using $0.2 \%$ Triton X-100, and copper-catalyzed click chemistry 
was performed to visualize proliferating cells using Alexa Fluor 488 azide (ThermoFisher). Cells were subsequently immunostained with rat anti-C-peptide antibody and goat anti-rat Alexa Fluor 647 (ThermoFisher) to mark $\beta$-cells along with DAPI as a nuclear counterstain. For each well, 16 fields were acquired using the Opera Phenix ${ }^{\mathrm{TM}}$ (PerkinElmer) and image analysis was performed using Harmony® Software (PerkinEImer) to calculate $\beta$-cell proliferation. 
Table S1. Donor Information

\begin{tabular}{|l|l|l|l|l|l|}
\hline & Batch-1 & Batch-2 & Batch-3 & Batch-4 & Batch-5 \\
\hline Donor ID & SAMN09767131 & $\begin{array}{l}\text { SAMN0992 } \\
9411\end{array}$ & $\begin{array}{l}\text { SAMN1039 } \\
1370\end{array}$ & SAMN10602026 & SAMN12496804 \\
\hline Purity & $80 \%$ & $90 \%$ & $90 \%$ & $90 \%$ & $90 \%$ \\
\hline Viability & $96 \%$ & $95 \%$ & $90 \%$ & $90 \%$ & $92 \%$ \\
\hline Health & Nondiabetic & Nondiabetic & Nondiabetic & Nondiabetic & Nondiabetic \\
\hline Age & 29 & 37 & 48 & 51 & 40 \\
\hline Gender & M & M & M & F & F \\
\hline BMI & 24.1 & 29 & 24.4 & 28.5 & 30.4 \\
\hline $\begin{array}{l}\text { Ethnicity/R } \\
\text { ace }\end{array}$ & Hispanic/Latino & $\begin{array}{l}\text { Black or } \\
\text { African } \\
\text { American }\end{array}$ & Hispanic & White & White \\
\hline $\begin{array}{l}\text { Cause of } \\
\text { Death }\end{array}$ & $\begin{array}{l}\text { Cerebrovascular/ } \\
\text { stroke }\end{array}$ & $\begin{array}{l}\text { Head } \\
\text { Trauma }\end{array}$ & $\begin{array}{l}\text { Head } \\
\text { Trauma }\end{array}$ & $\begin{array}{l}\text { Cerebrovascular/ } \\
\text { stroke }\end{array}$ & $\begin{array}{l}\text { Cerebrovascular/ } \\
\text { stroke }\end{array}$ \\
\hline Source & $\begin{array}{l}\text { Southern } \\
\text { California Islet } \\
\text { Cell Resources } \\
\text { Center }\end{array}$ & $\begin{array}{l}\text { The Scharp- } \\
\text { Lacy } \\
\text { Research } \\
\text { Institute }\end{array}$ & $\begin{array}{l}\text { University of } \\
\text { Miami }\end{array}$ & $\begin{array}{l}\text { University of } \\
\text { Miami }\end{array}$ & $\begin{array}{l}\text { University of } \\
\text { Miami }\end{array}$ \\
\hline
\end{tabular}


Table S2. Primary antibodies to all antigens and appropriate secondary antibodies

\begin{tabular}{|c|c|c|}
\hline REAGENT or RESOURCE & SOURCE & IDENTIFIER \\
\hline \multicolumn{3}{|l|}{ Antibodies } \\
\hline Rat anti-C-Peptide (1:100) & $\begin{array}{l}\text { Developmental Studies } \\
\text { Hybridoma Bank }\end{array}$ & GN-ID4; RRID: AB_2255626 \\
\hline Guinea Pig anti-Insulin (1:400) & Abcam & ab7842; RRID: $\underline{A B} 306130$ \\
\hline $\begin{array}{l}\text { Mouse anti-Glucagon } \\
(1: 10,000)\end{array}$ & Sigma & G2654; RRID: AB_259852 \\
\hline Rat anti-Somatostatin (1:100) & Abcam & ab30788; RRID: AB_778010 \\
\hline Goat anti-PPY (1:150) & Novus & NB 100-1793, RRID: AB_526299 \\
\hline $\begin{array}{l}\text { Donkey anti-Guinea Pig AF594 } \\
(1: 400)\end{array}$ & Jackson ImmunoResearch & $\begin{array}{l}\text { 706-586-148; RRID: } \\
\text { AB 42340475 }\end{array}$ \\
\hline $\begin{array}{l}\text { Donkey anti-Guinea Pig AF488 } \\
(1: 400)\end{array}$ & Jackson ImmunoResearch & 706-546-148; RRID: AB_2340473 \\
\hline Donkey anti-Rat AF488 (1:400) & Jackson ImmunoResearch & 712-546-153; RRID: $\underline{A B \quad 2340686}$ \\
\hline $\begin{array}{l}\text { Donkey anti-Mouse AF594 } \\
(1: 400)\end{array}$ & Jackson ImmunoResearch & 715-586-150; RRID: \\
\hline $\begin{array}{l}\text { Donkey anti-Mouse AF488 } \\
(1: 400)\end{array}$ & Jackson ImmunoResearch & 715-546-150; RRID: AB_2340849 \\
\hline $\begin{array}{l}\text { Donkey anti-Goat AF594 } \\
(1: 400)\end{array}$ & Jackson ImmunoResearch & 705-586-147; RRID: AB_2340434 \\
\hline DAPI, dilactate & Sigma & D9564 \\
\hline $\begin{array}{l}\text { CMRL } 1066 \text { final wash/culture } \\
\text { medium }\end{array}$ & Mediatech & $99-785-\mathrm{CV}$ \\
\hline Supplemented CMRL 1066 & Mediatech & $99-603-\mathrm{CV}$ \\
\hline TrypLE & Thermo Fisher Scientific & $12604-013$ \\
\hline DMEM HG (no phenol red) & Thermo Fisher Scientific & 21063029 \\
\hline Penicillin-streptomycin & Corning & $30-002-\mathrm{Cl}$ \\
\hline FBS & Thermo Fisher Scientific & 10437028 \\
\hline
\end{tabular}


Dose and Time-dependent of beta-cell specific hydrolysis with DA-ZP1

A

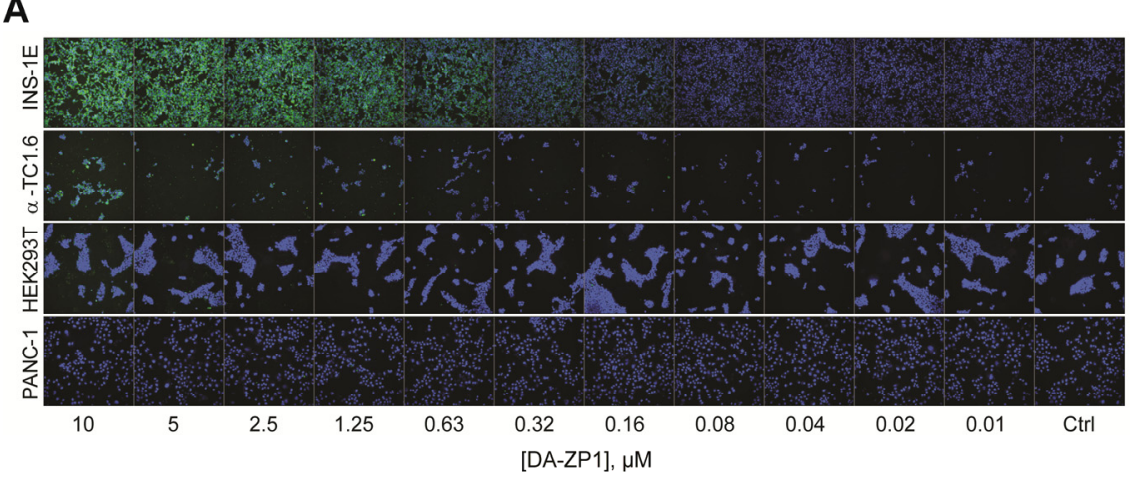

C

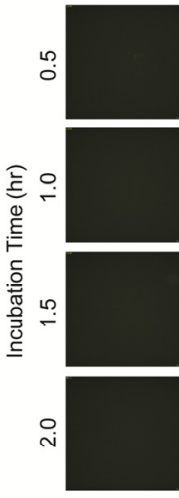

Ctrl
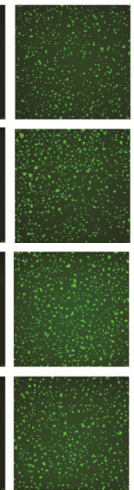

10
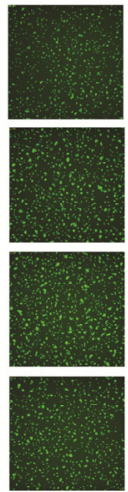

5
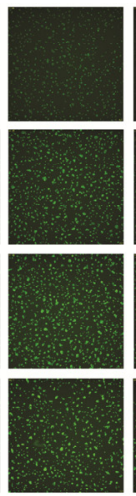

25
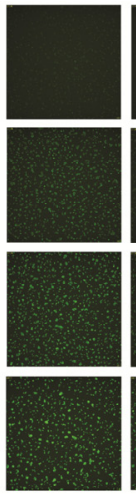

1.25
B
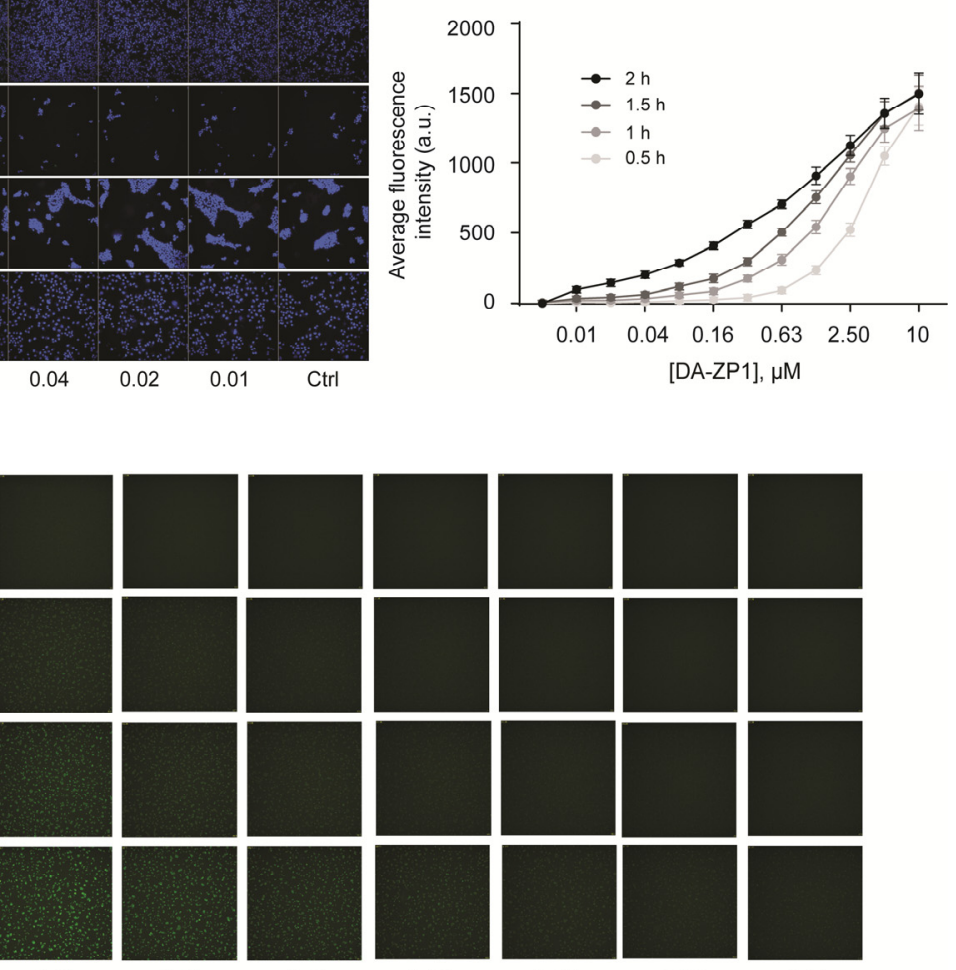

0.63

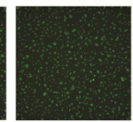

0.32

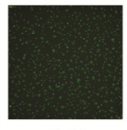

0.16

0.08
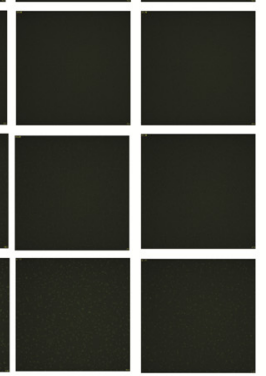

0.02

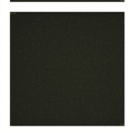

0.01

Figure S1. (A) $\beta$-cell-specific hydrolysis of DA-ZP1 unmasks fluorescence in a dose-dependent manner after $1 \mathrm{~h}$ of compound incubation at different concentrations. Each panel represents a merged FITC and DAPI channel. (B) Fluorescence release kinetics in INS-1E cells at increasing concentrations of DA-ZP1. (C) Time-dependent unmasking of DA-ZP1 in INS-1E cells imaged with the FITC channel. 
Evaluation of the intracellular localization of DA-ZP1 and Zn(II) depletion

A

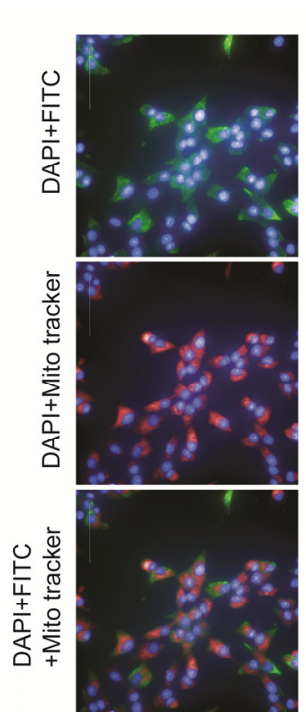

B
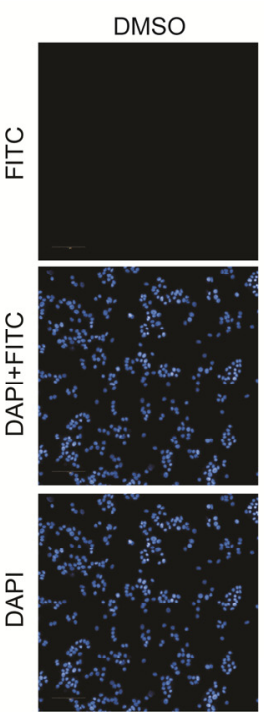

DA-ZP1
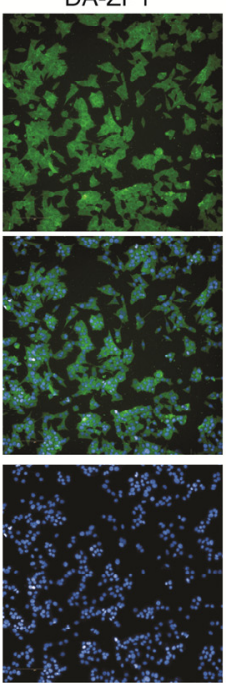

TPEN+DA-ZP1
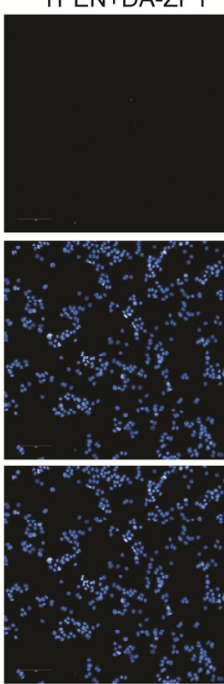

Figure S2. (A) Cellular localization of ZP1 in INS1E cells. Cells were treated with DA-ZP1 (5 $\mu M)$ for $1 \mathrm{~h}$ followed by fluorescence imaging using DAPI and MitoTracker as counterstaining for nuclei and mitochondria, respectively. (B) Fluorescence image showing inhibition of DA-ZP1 (5 $\mu \mathrm{M})$ staining after 30 min of incubation with INS1E cells in the presence of metal chelator (TPEN, $25 \mu \mathrm{M}$ ). 


\section{Sorting human pancreatic beta cells using DA-ZP1}

A

$\begin{gathered}\text { Cadaveric } \\ \text { human islets } \\ \text { O/n culture }\end{gathered} \longrightarrow \begin{gathered}\text { Disperse } \\ \text { human islets } \\ \text { in single cells }\end{gathered} \longrightarrow \quad \begin{gathered}\text { DA-ZP1 } \\ \text { staining and } \\ \text { FACS-sorting }\end{gathered}$
$\begin{gathered}\text { DA-ZP1- } \\ \text { cells }\end{gathered}$

B

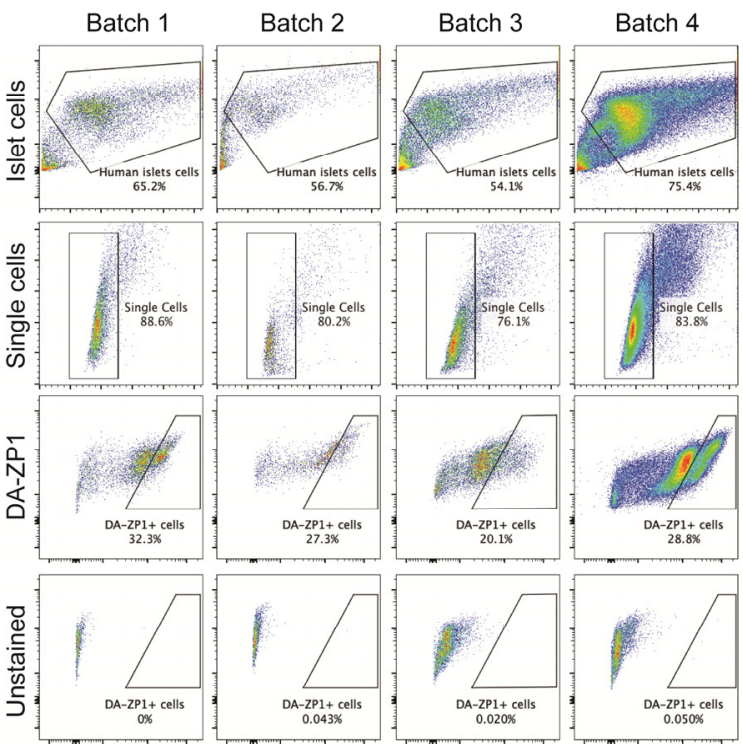

C

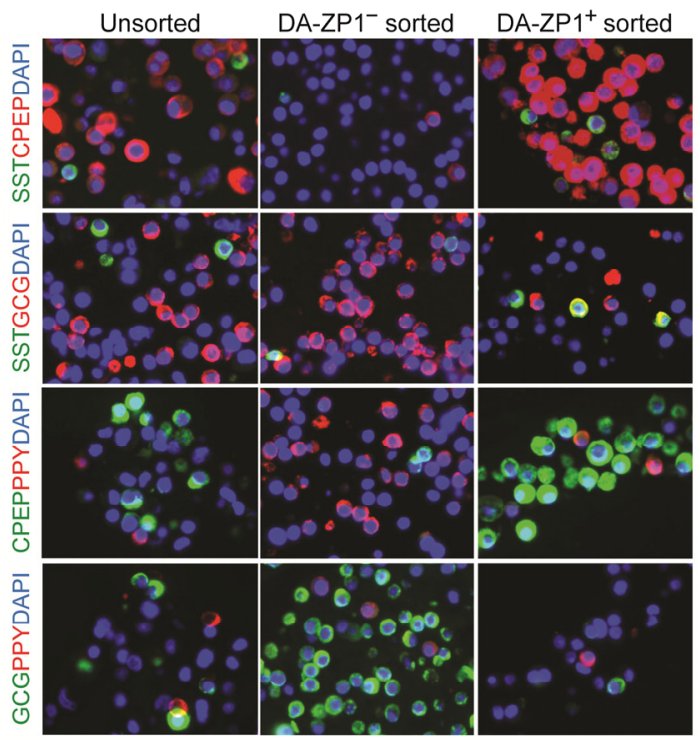

Figure S3. (A) Overview of DA-ZP1-based experimental approach for human pancreatic islets cell sorting. (B) Representative flow plots show the sorting of human islets cells from four different donors. The gating strategy is shown in each plot by labeling the gated population. Cell debris was excluded by forwarding versus side scatter (FSC-A vs SSC-A) and singlets were identified by forward scatter area versus wide (FSC-A vs FSC-W). DA-ZP1 stained cells were isolated according to unstained samples. (C) DA-ZP1+ and DA-ZP1- human islet cells were collected by FACS. Cells were embedded in agarose and paraffin for sectioning. Slides were stained for islet hormones. Representative images show insulin (CPEP), glucagon (GCG), somatostatin (SST), pancreatic polypeptide (PPY) staining in unsorted, DA-ZP1+', DA-ZP1- cell populations. Nuclei stained with DAPI (blue). 


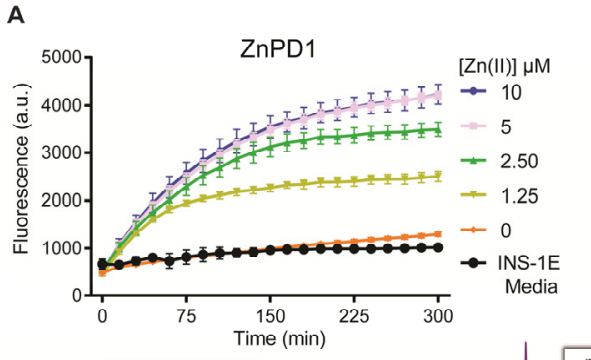

D

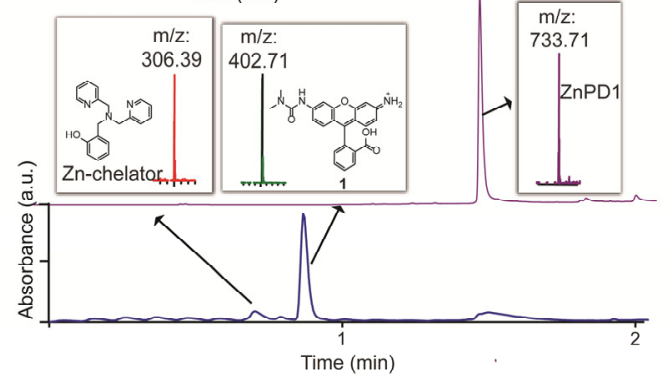

B

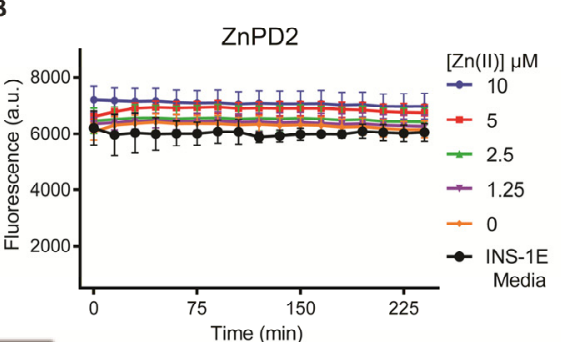

E

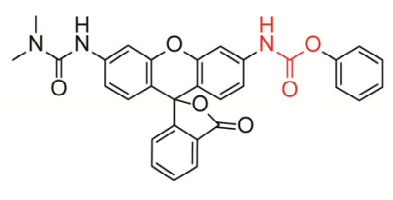

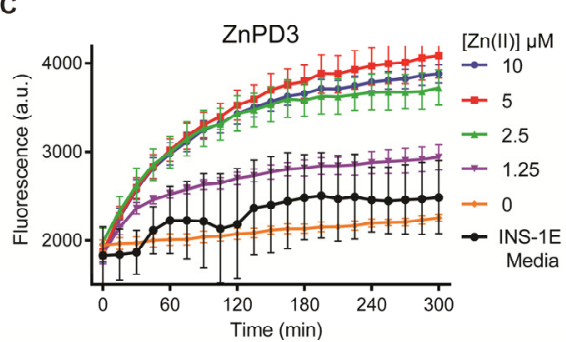

$\mathbf{F}$

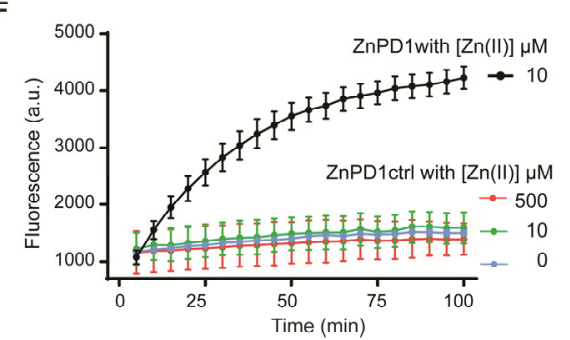

Figure S4. (A) Zn(II)-mediated hydrolysis of ZnPD1 (10 $\mu \mathrm{M})$ in PBS buffer (pH 7.4). (B) Zn(II)-mediated hydrolysis of ZnPD2 (10 $\mu \mathrm{M})$ in PBS buffer (pH 7.4). (C) Zn(II)-mediated hydrolysis of ZnPD3 (10 $\mu \mathrm{M})$ in PBS buffer (pH 7.4). (D) LC-MS chromatogram of Zn(II)-mediated (10 $\mathrm{MM}$ ) hydrolysis of ZnPD1 (10 $\mu \mathrm{M})$ in PBS buffer (pH 7.4). (E) Chemical structure of ZnPD1ctrl. (F) A comparison of Zn(II)-mediated hydrolysis between ZnPD1 $(10 \mu \mathrm{M})$ and ZnPD1ctrl $(10 \mu \mathrm{M})$ in PBS buffer $(\mathrm{pH} 7.4)$. Excitation and emission wavelength of $490 \mathrm{~nm}$ and $522 \mathrm{~nm}$ were used for the studies.

\section{Dose-dependent of beta-cell specific hydrolysis of ZnPD1}

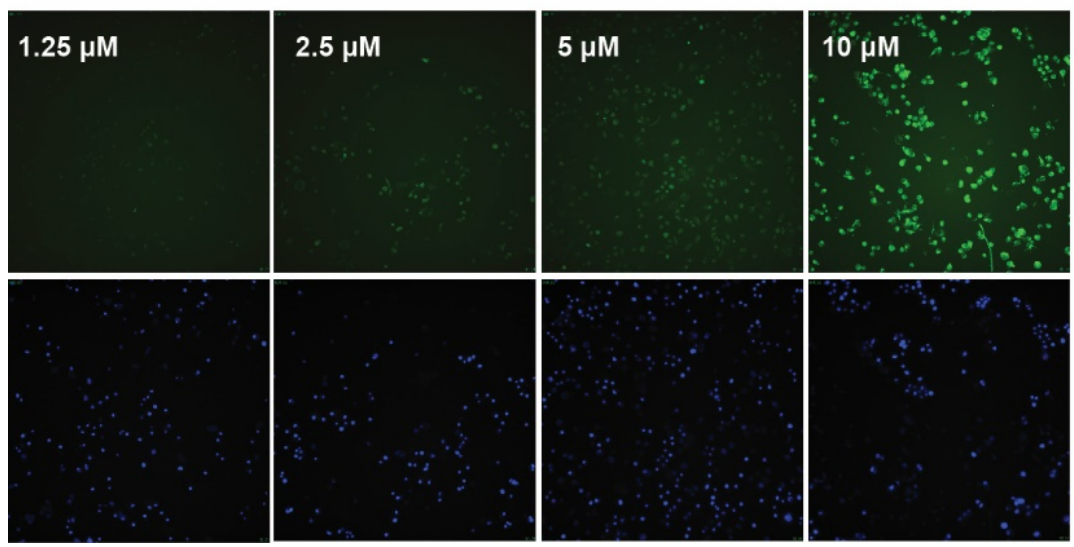

Figure S5. Dose-dependent release of rhodamine urea from ZnPD1 in INS-1E cells after $1 \mathrm{~h}$ of incubation. Top and bottom panels represent images acquired in FITC and DAPI channels, respectively. 
Dose and Time-dependent of beta-cell specific hydrolysis with ZnPD4

A

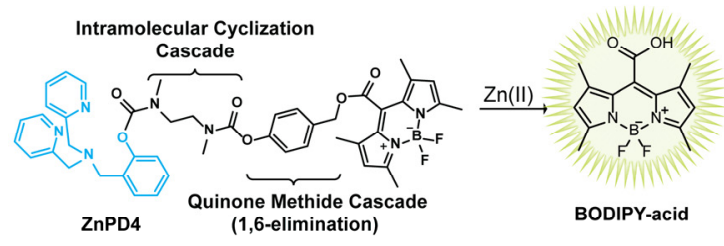

C

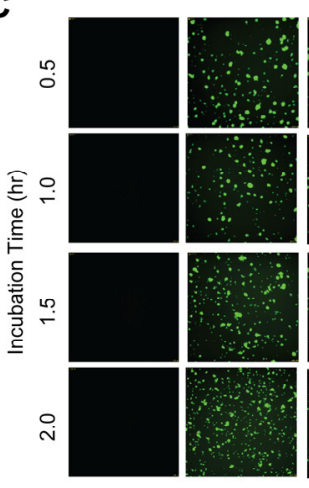

Ctrl

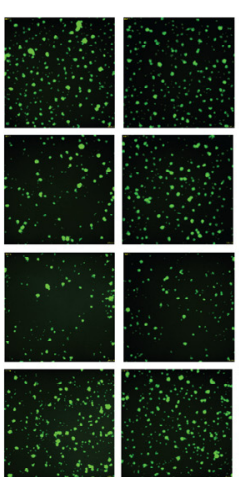

2.5

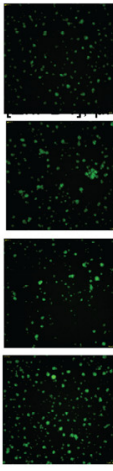

1.25

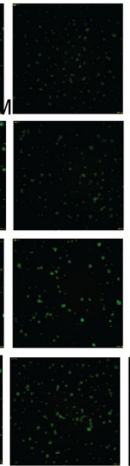

0.63
B
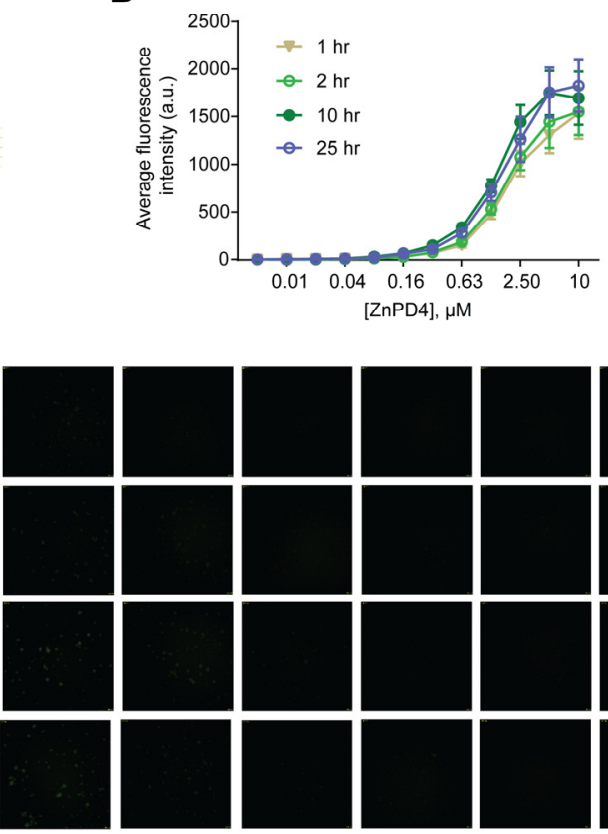

0.32

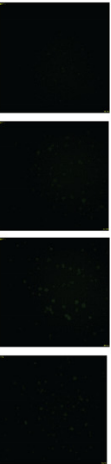

0.16

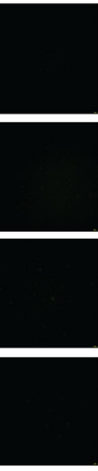

0.08

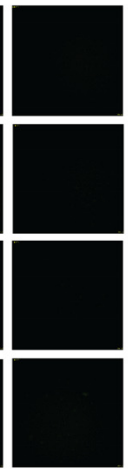

0.04

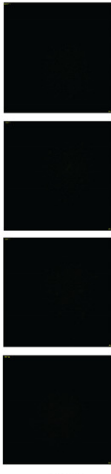

0.02

0.01

Figure S6. (A) Proposed mechanism of Zn(II)-mediated hydrolysis of ZnPD4. (B) Time-dependent release of BODIPY acid (compound 2) from ZnPD4 in INS-1E cells by Zn(II)-mediated hydrolysis followed by selfimmolation. (C) Representative images of the time-dependent release of BODIPY acid from ZnPD4 in INS$1 \mathrm{E}$ cells imaged with the FITC channel. 


\section{Sorting human pancreatic beta cells using ZnPD4}

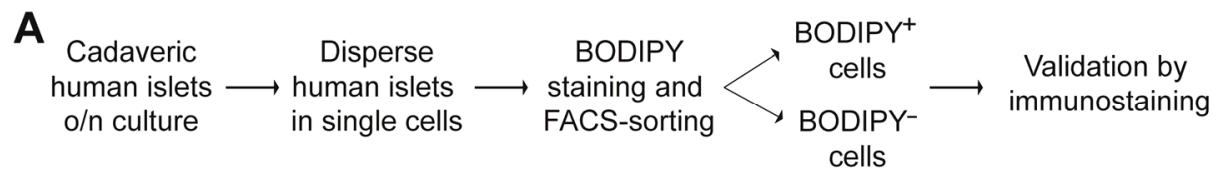

B

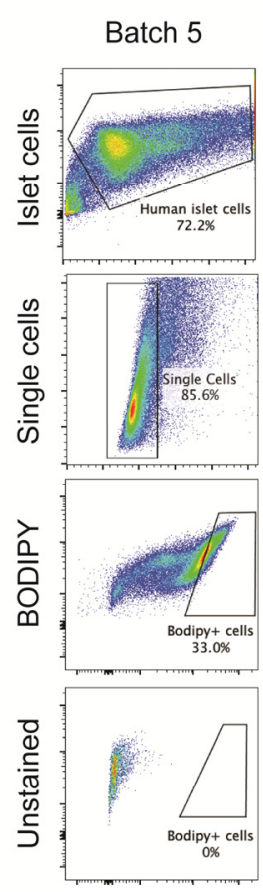

C

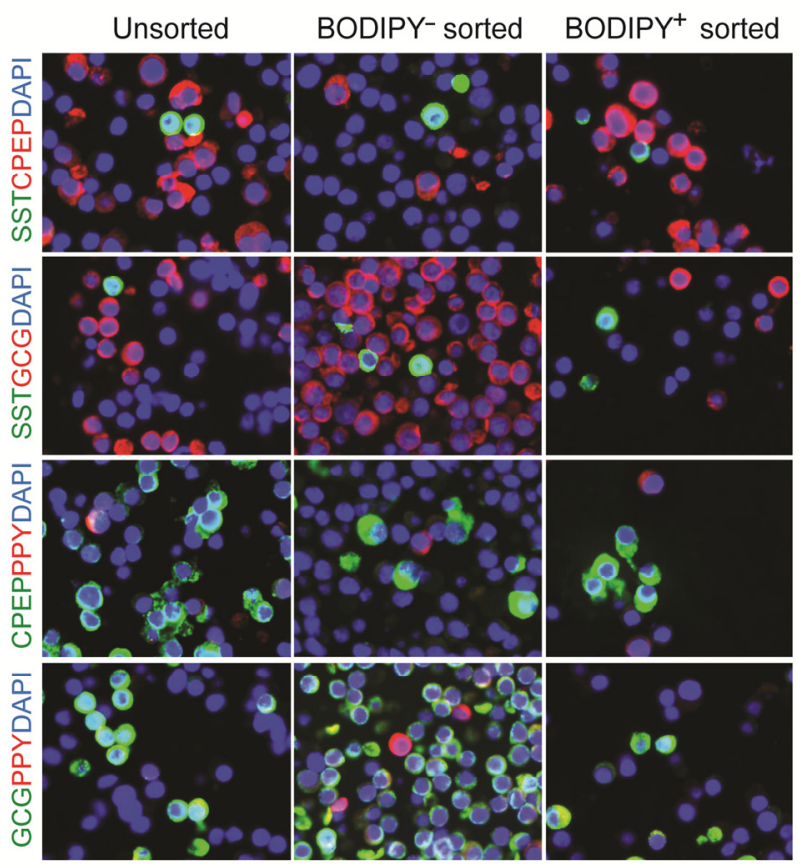

Figure S7. (A) Overview of BODIPY staining analysis and experimental approach for human pancreatic islets. (B) Representative flow plots show the sorting of human islets cells from a single donor. Cell debris was excluded by forwarding versus side scatter (FSC-A vs SSC-A) and singlets were identified by forward scatter area versus wide (FSC-A vs FSC-W). BODIPY stained cells were isolated according to unstained samples. (C) BODIPY+ and BODIPY- human islet cells were collected after FACS. Cells were embedded in agarose and paraffin for sectioning. Slides were stained for islet hormones. Representative images show insulin (CPEP), glucagon (GCG), somatostatin (SST), pancreatic polypeptide (PPY) staining in unsorted, BODIPY $^{+}$and BODIPY- cell populations. Nuclei stained with DAPI (blue). 


\section{Zn(II)-mediated hydrolysis of ZnPD5}

A

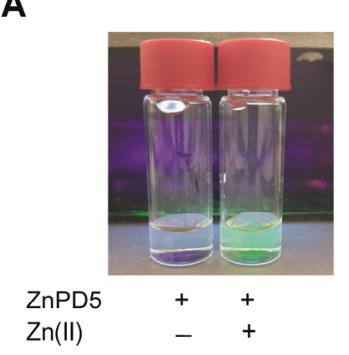

B

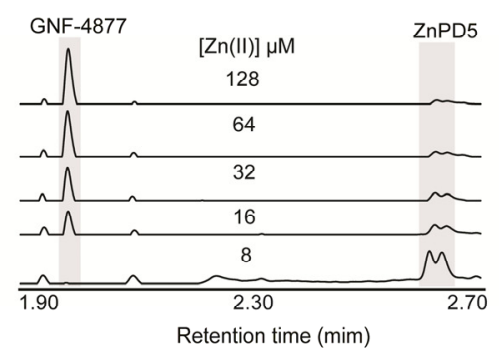

C

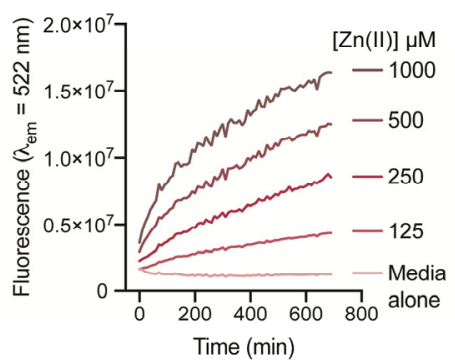

D
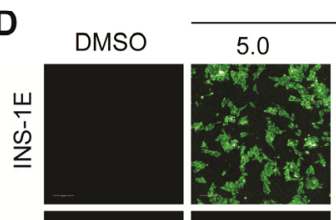

[ZnPD5] $\mu \mathrm{M}$
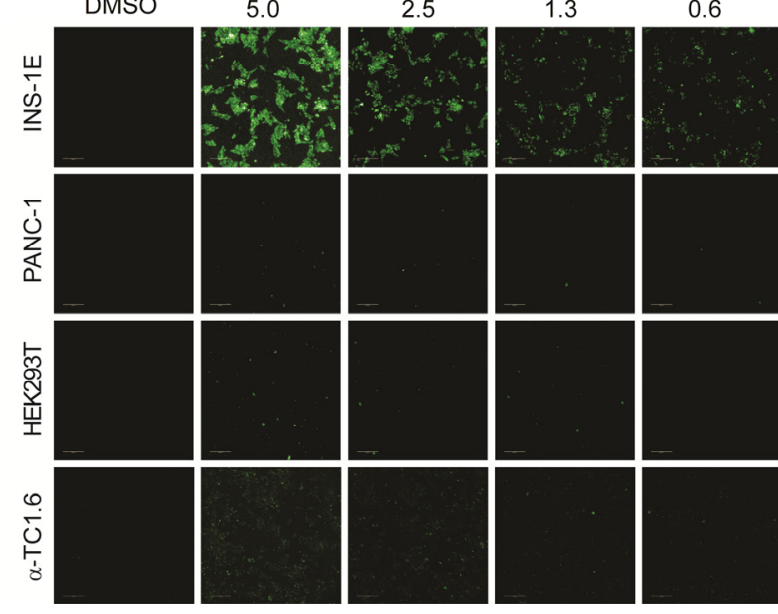

E

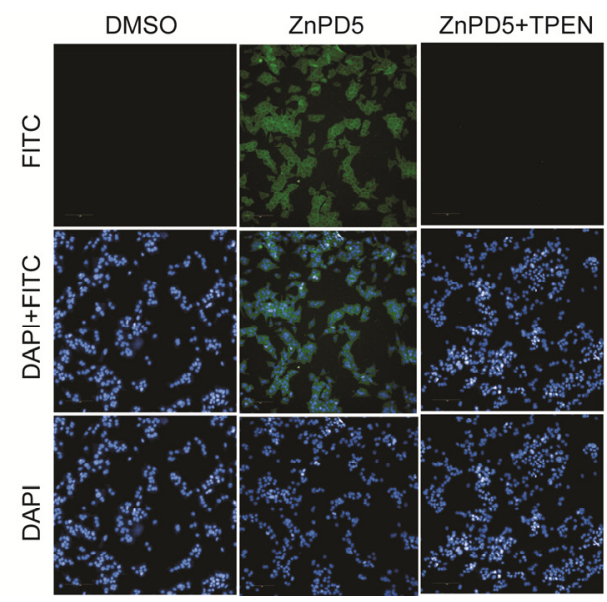

Figure S8. (A) The appearance of fluorescence signal after Zn(II)-mediated uncaging of ZnPD5. Images were captured under UV light $(\lambda=365 \mathrm{~nm})$. (B) Kinetic profile of GNF-4877 (compound 3) release from ZnPD5 (10 $\mu \mathrm{M})$ upon incubation with different amounts (8-128 $\mu \mathrm{M})$ of $\mathrm{Zn}(\mathrm{II})$ in PBS. (C) Stability of ZnPD5 $(10 \mu \mathrm{M})$ in INS1E cell culture medium alone and after addition of different amounts of $\mathrm{Zn}(\mathrm{II})(125-1000 \mu \mathrm{M})$ monitored by the fluorescence signal $\left(\lambda_{\mathrm{ex}}=490 \mathrm{~nm}, \lambda_{\mathrm{em}}=522 \mathrm{~nm}\right)$ of the released ZP1. (D) Representative images of the dose-dependent release of GNF-4877 (compound 3) from ZnPD5 in INS-1E cells in the FITC channel. (E) Fluorescence image showing inhibition of ZnPD5 (5 $\mu \mathrm{M})$ staining of INS1E cells in the presence of a metal chelator (TPEN, $25 \mu \mathrm{M})$. 


\section{Zn(II)-mediated hydrolysis of ZnPD5 in Human Islet}

A

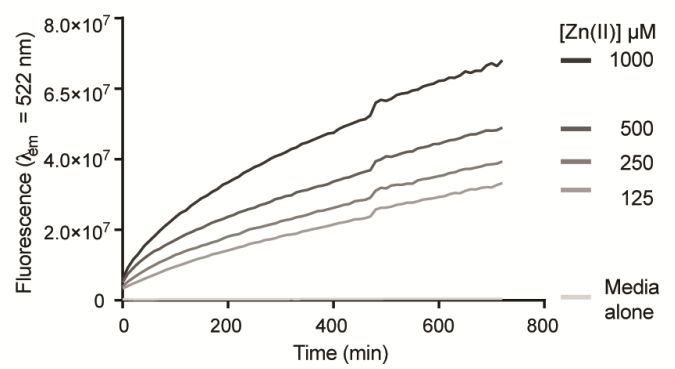

B
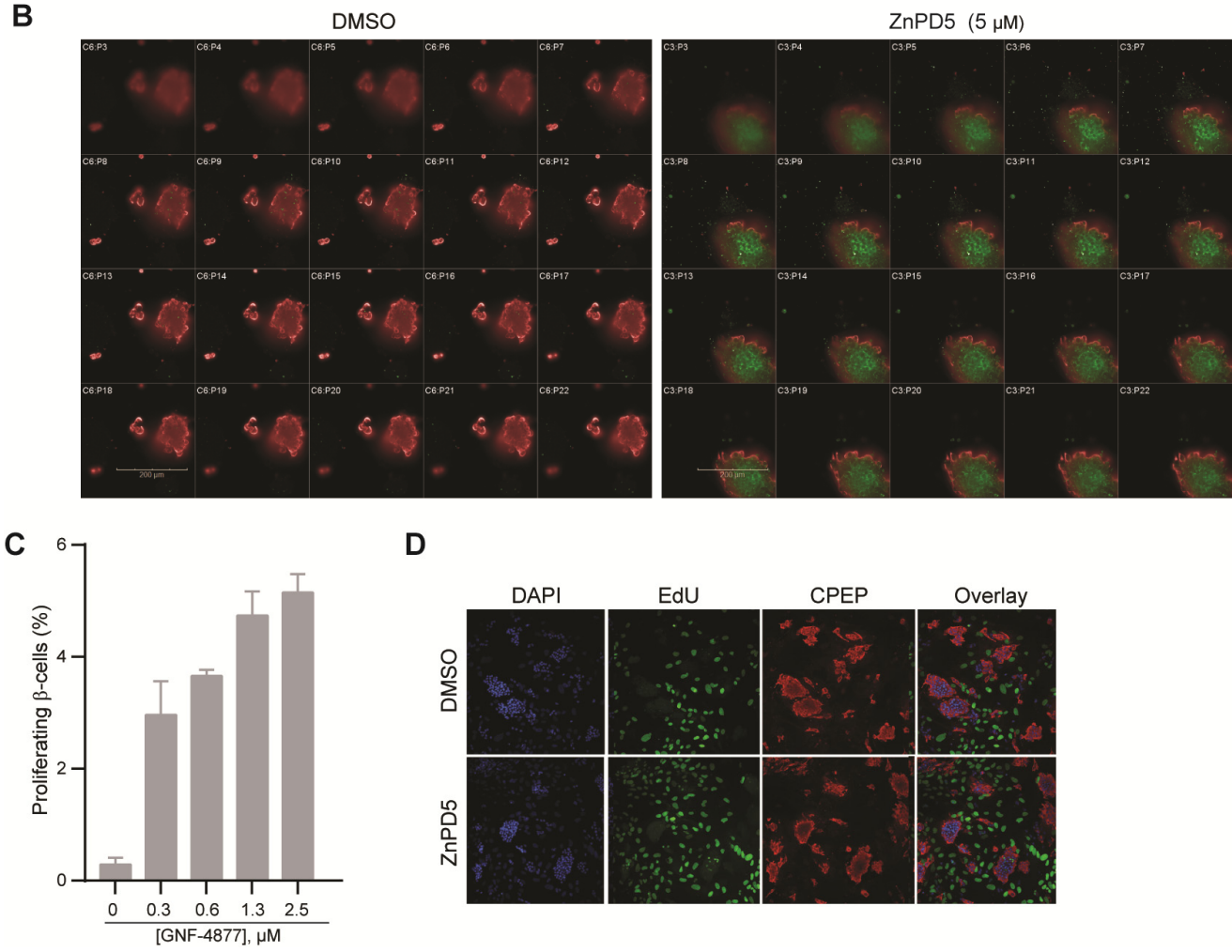

D

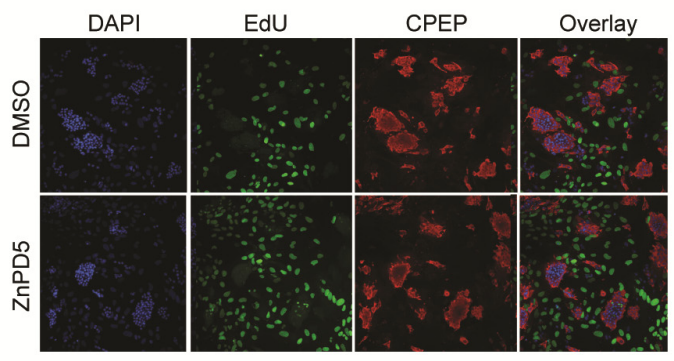

Figure S9. (A) Stability of ZnPD5 $(10 \mu \mathrm{M})$ in human islet cell culture medium alone and after addition of different amount of $\mathrm{Zn}(\mathrm{II})(125-1000 \mu \mathrm{M})$ monitored by the fluorescence signal $\left(\lambda_{\mathrm{ex}}=490 \mathrm{~nm}, \lambda_{\mathrm{em}}=522\right.$ $\mathrm{nm}$ ) of the released ZP1. (B) $\beta$-cell-selective staining of ZnPD5 in intact human islets. Undissociated human islets were incubated with either DMSO or ZnPD5 $(5 \mu \mathrm{M})$ for $3 \mathrm{~h}$ in culture medium in the incubator before processing for immunostaining and confocal fluorescence microscopy. Islets were imaged at 18 different planes with $1 \mu \mathrm{m}$ spacing. Anti-C-peptide antibody (red) was used as the $\beta$-cell counterstaining and the FITC channel represents the dissociated ZnPD5. The co-localization of FITC and red signal indicates the $\beta$-cell-selective release of ZnPD5. (C) Proliferation profile of human islet $\beta$-cells after incubating with GNF-4877 (0-2.5 $\mu \mathrm{M})$ for 6 days. (D) Representative images for proliferative human islet cells as probed with EdU assay. Cells were cultured in the presence of EdU (10 $\mu \mathrm{M})$ and ZnPD5 (2.5 $\mu \mathrm{M})$ for 6 days. Green and red channels represent EdU and anti-C-Peptide staining, respectively. 
${ }^{1} \mathrm{H}$ and ${ }^{13} \mathrm{C}$ NMR spectra of ZnPDs

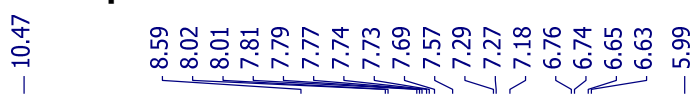<smiles>CN(C)C(=O)Nc1ccc2c(c1)Oc1cc(NC(=O)OCCl)ccc1C2(C(=O)O)c1ccccc1</smiles>

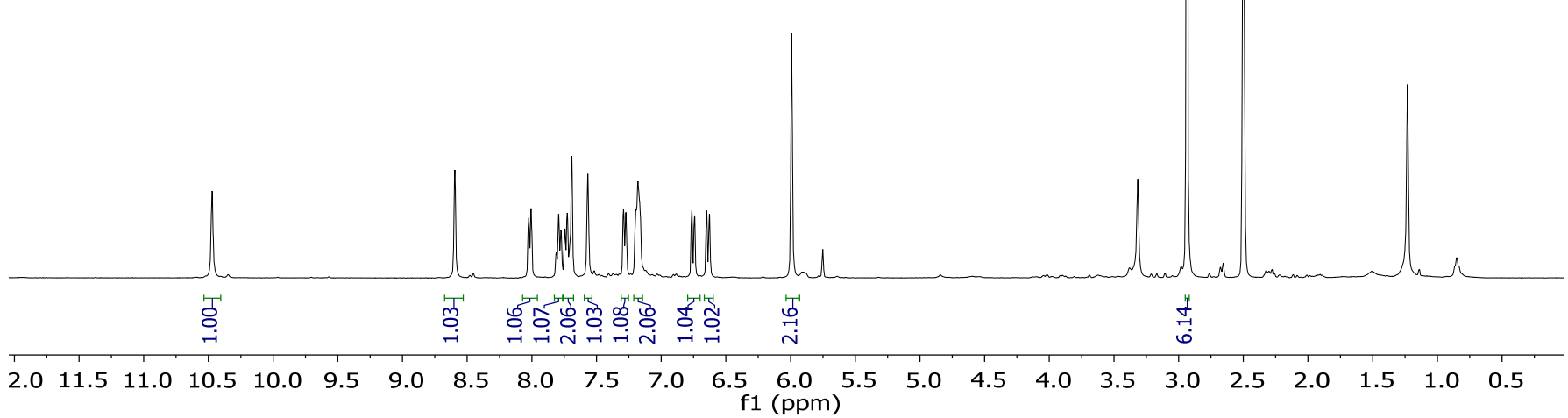

Figure S10. ${ }^{1} \mathrm{H}$ NMR spectrum of compound 1.

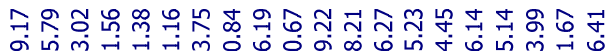

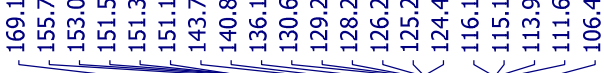<smiles>CN(C)C(=O)Nc1ccc2c(c1)Oc1cc(NC(=O)OCCl)ccc1C21OC(=O)c2ccccc21</smiles> 


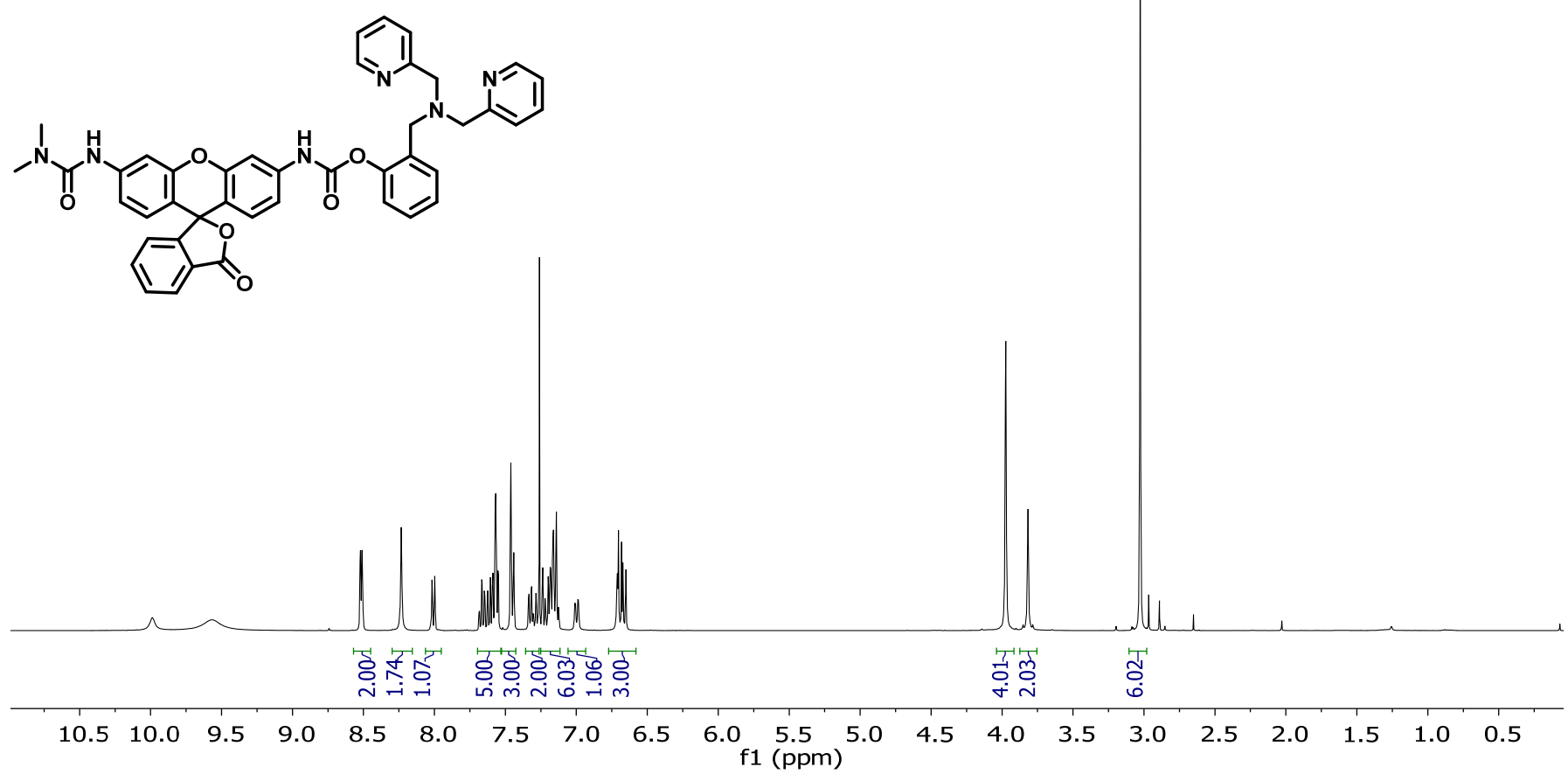

Figure S12. ${ }^{1} \mathrm{H}$ NMR spectrum of ZnPD1.<smiles>CN(C)C(=O)Nc1ccc2c(c1)Oc1cc(NC(=O)Oc3ccccc3CN(Cc3ccccn3)Cc3ccccn3)ccc1C21OC(=O)c2ccccc21</smiles>

Figure S13. ${ }^{13} \mathrm{C}$ NMR spectrum of ZnPD1. 
<smiles>CN(C)C(=O)Nc1ccc2c(c1)Oc1cc(NC(=O)Oc3ccc(F)cc3CN(Cc3ccccn3)Cc3ccccn3)ccc1C21OC(=O)c2ccccc21</smiles>

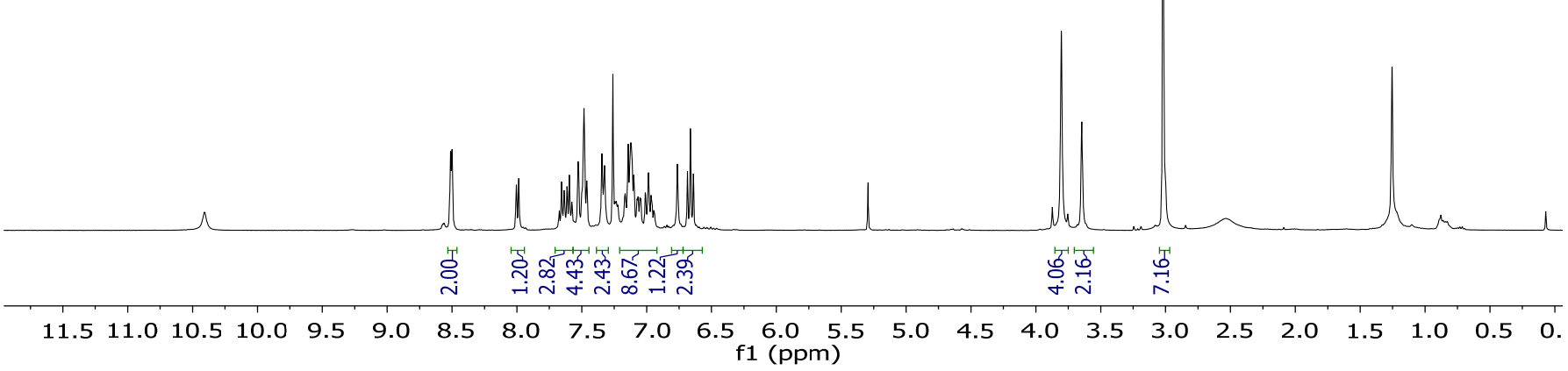

Figure S14. ${ }^{1} \mathrm{H}$ NMR spectrum of ZnPD3.<smiles>CN(C)C(=O)Nc1ccc2c(c1)Oc1cc(NC(=O)Oc3ccc(F)cc3CN(Cc3ccccn3)Cc3ccccn3)ccc1C21OC(=O)c2ccccc21</smiles>

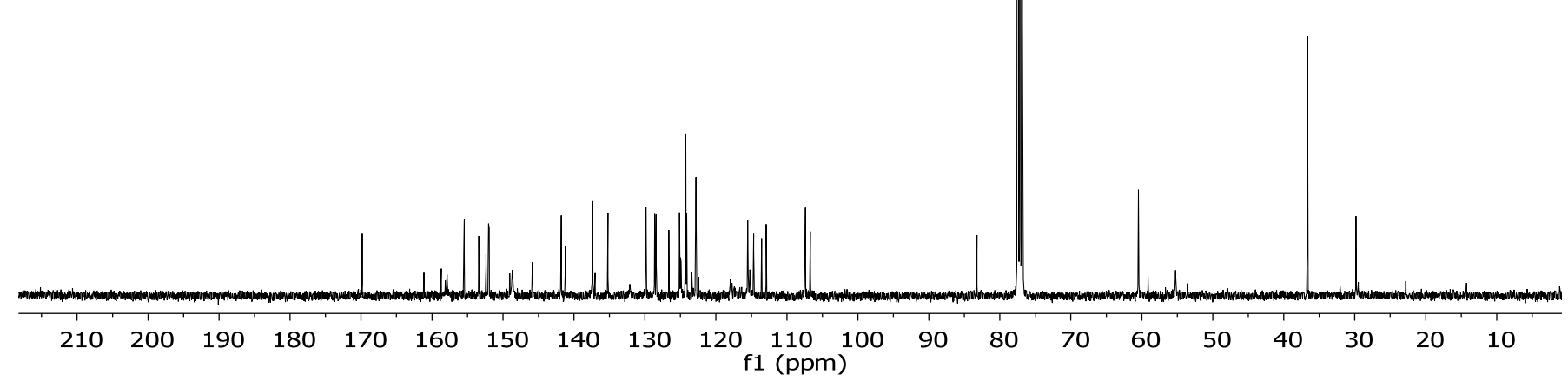

Figure S15. ${ }^{13} \mathrm{C}$ NMR spectrum of ZnPD3. 


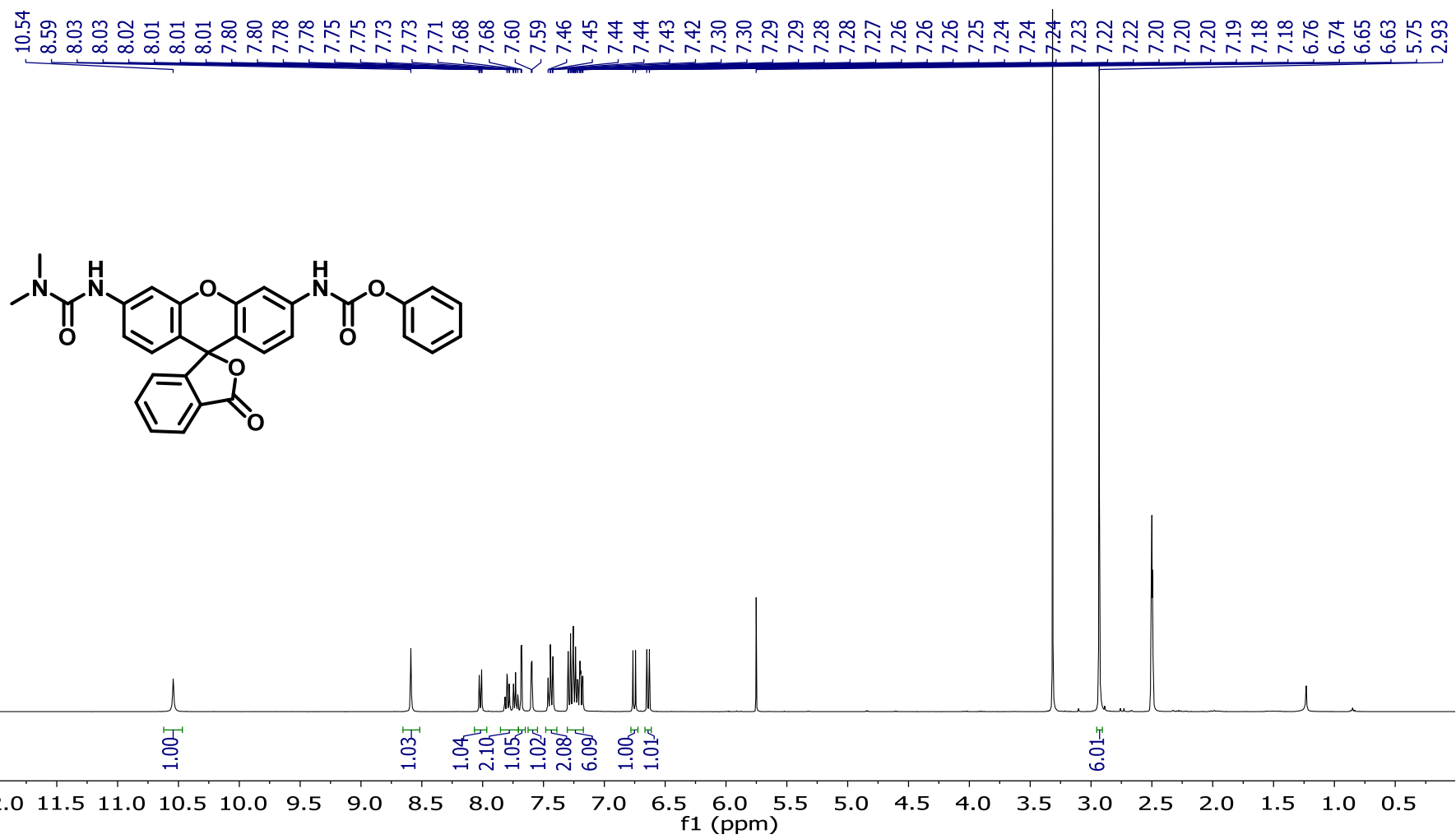

Figure S16. ${ }^{1} \mathrm{H}$ NMR spectrum of ZnPD1ctrl.<smiles>CN(C)C(=O)Nc1ccc2c(c1)Oc1cc(NC(=O)Oc3ccccc3)ccc1C21OC(=O)c2ccccc21</smiles>

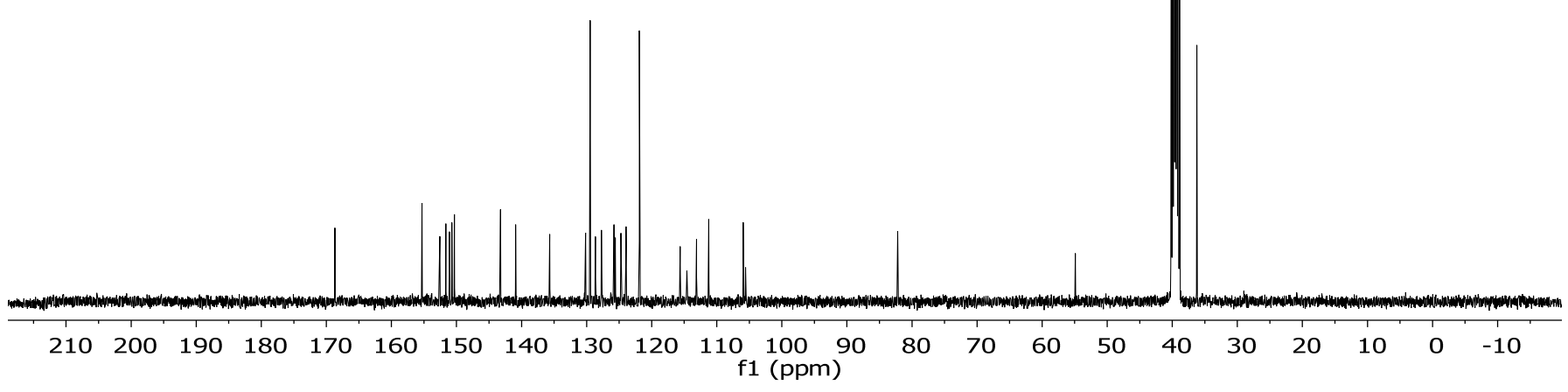

Figure S17. ${ }^{13} \mathrm{C}$ NMR spectrum of ZnPD1 ctrl. 

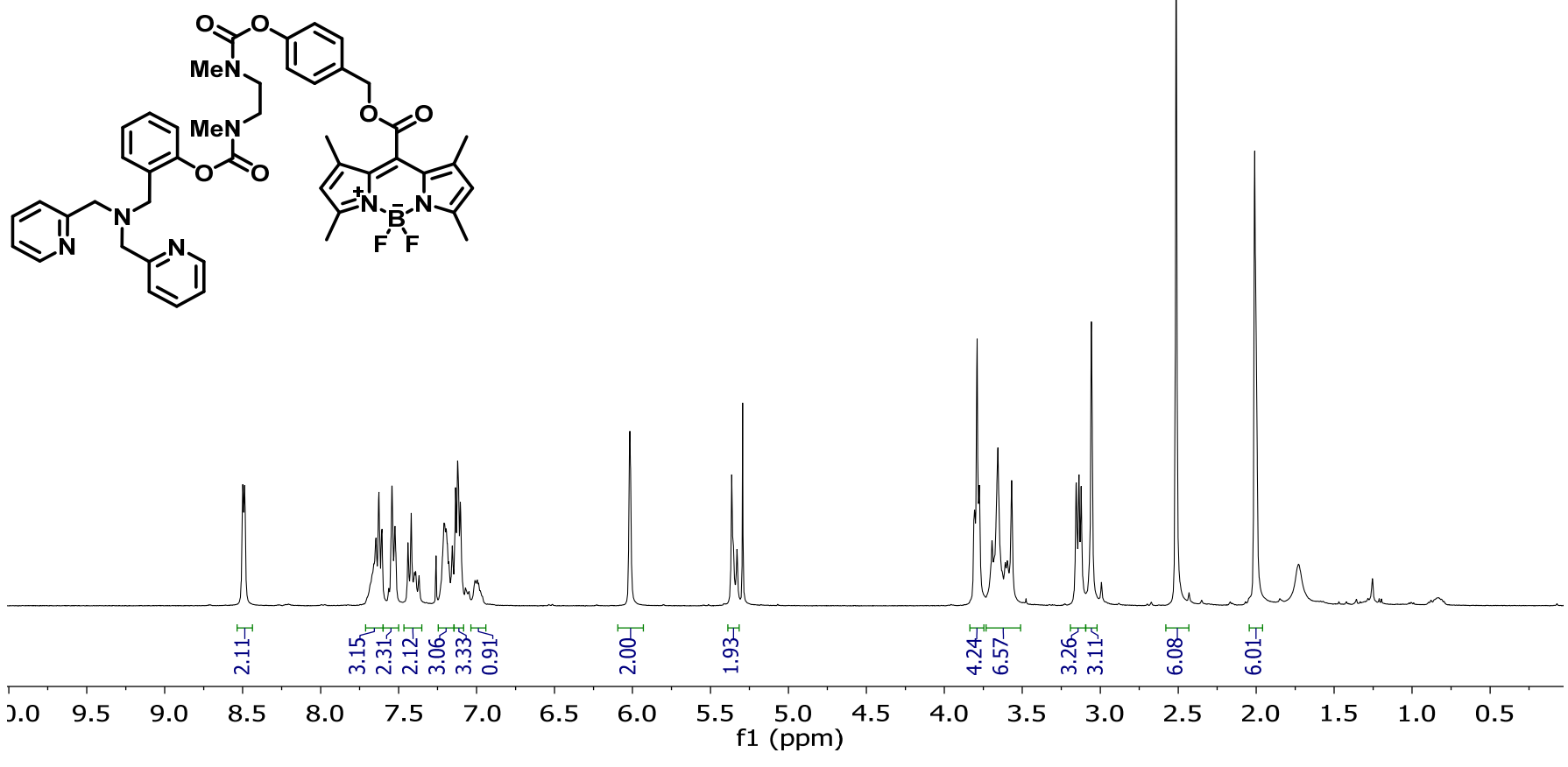

Figure S18. ${ }^{1} \mathrm{H}$ NMR spectrum of ZnPD4.

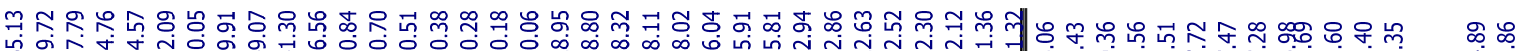

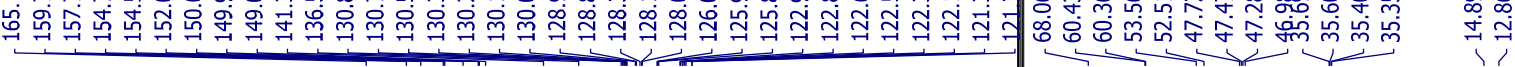

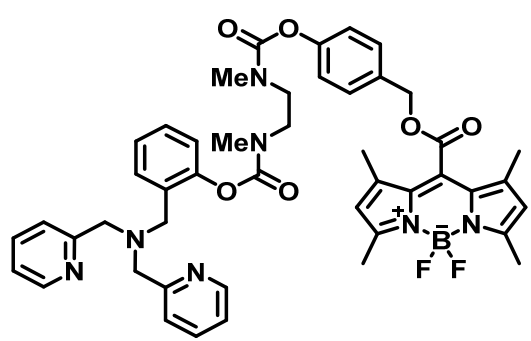

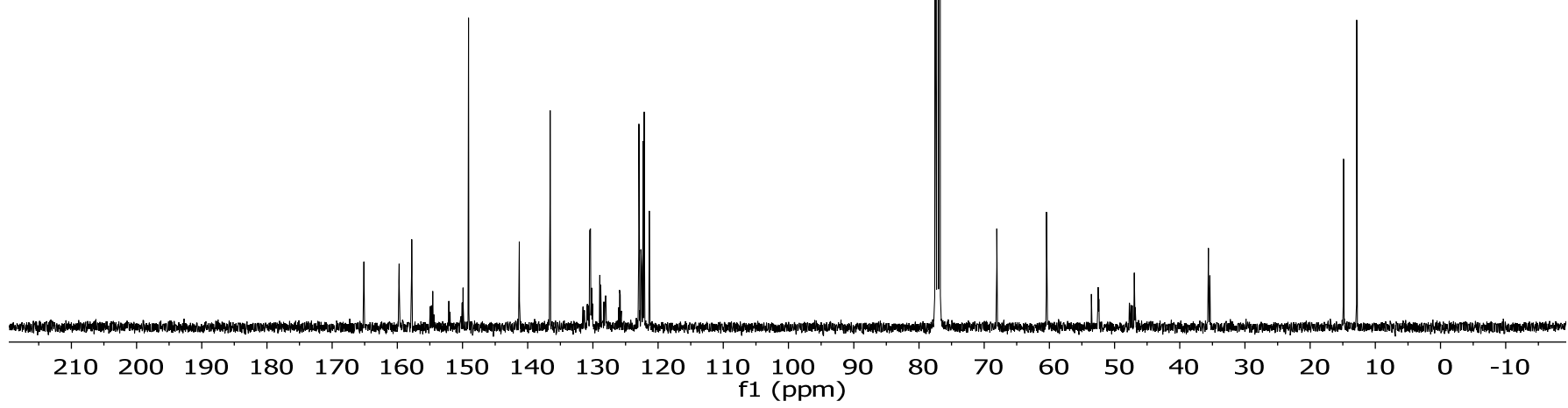

Figure S19. ${ }^{13} \mathrm{C}$ NMR spectrum of ZnPD4. 


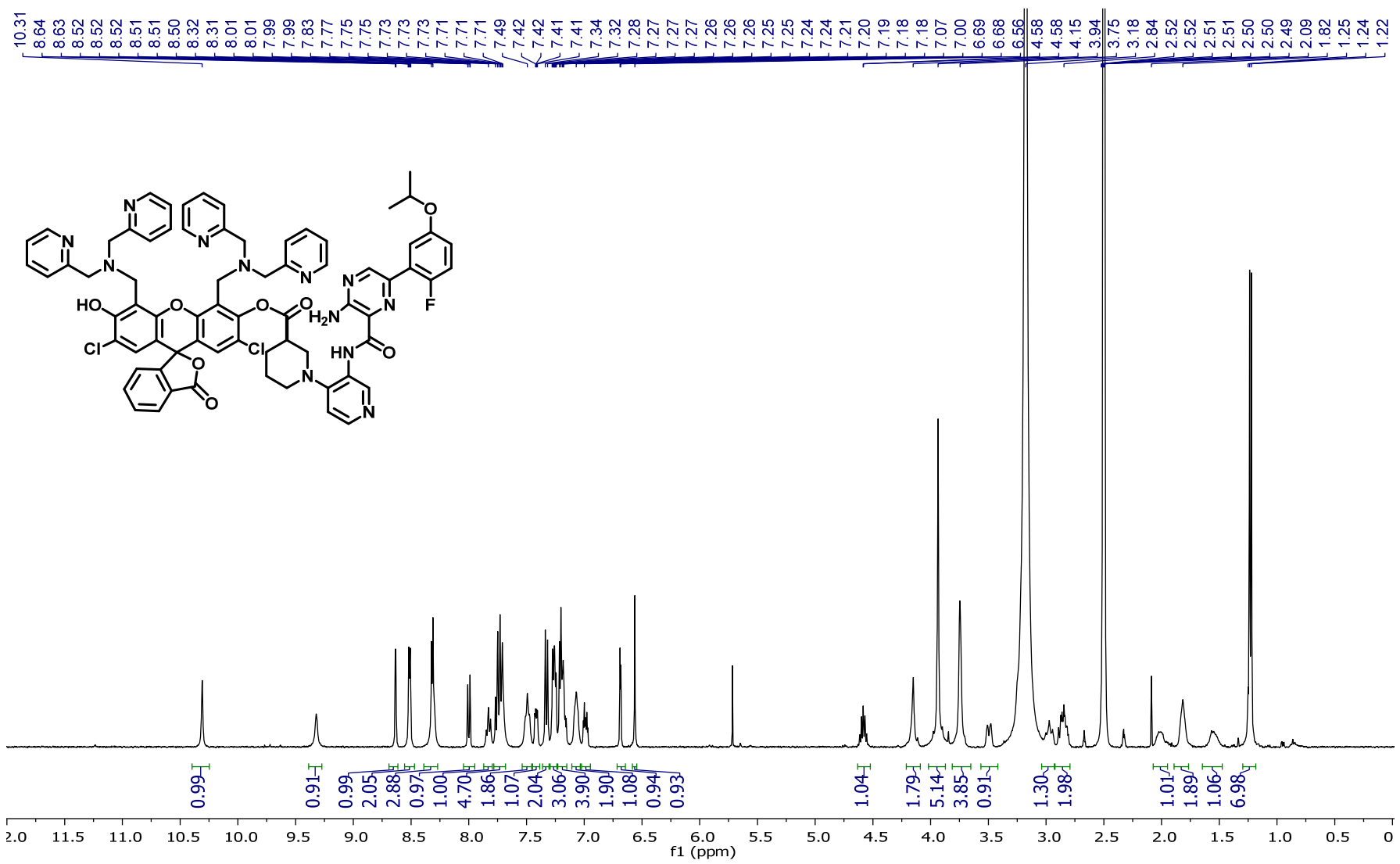

Figure S20. ${ }^{1} \mathrm{H}$ NMR spectrum of ZnPD5.

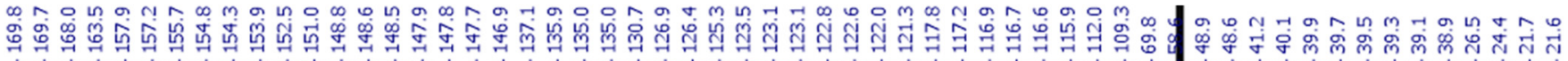

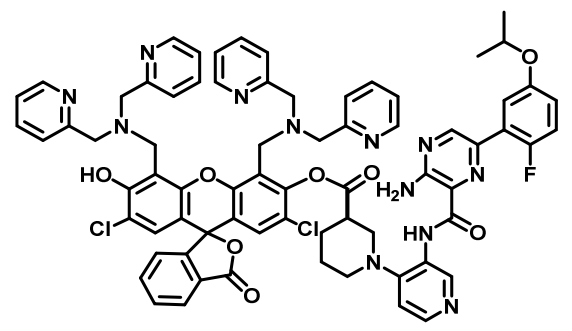
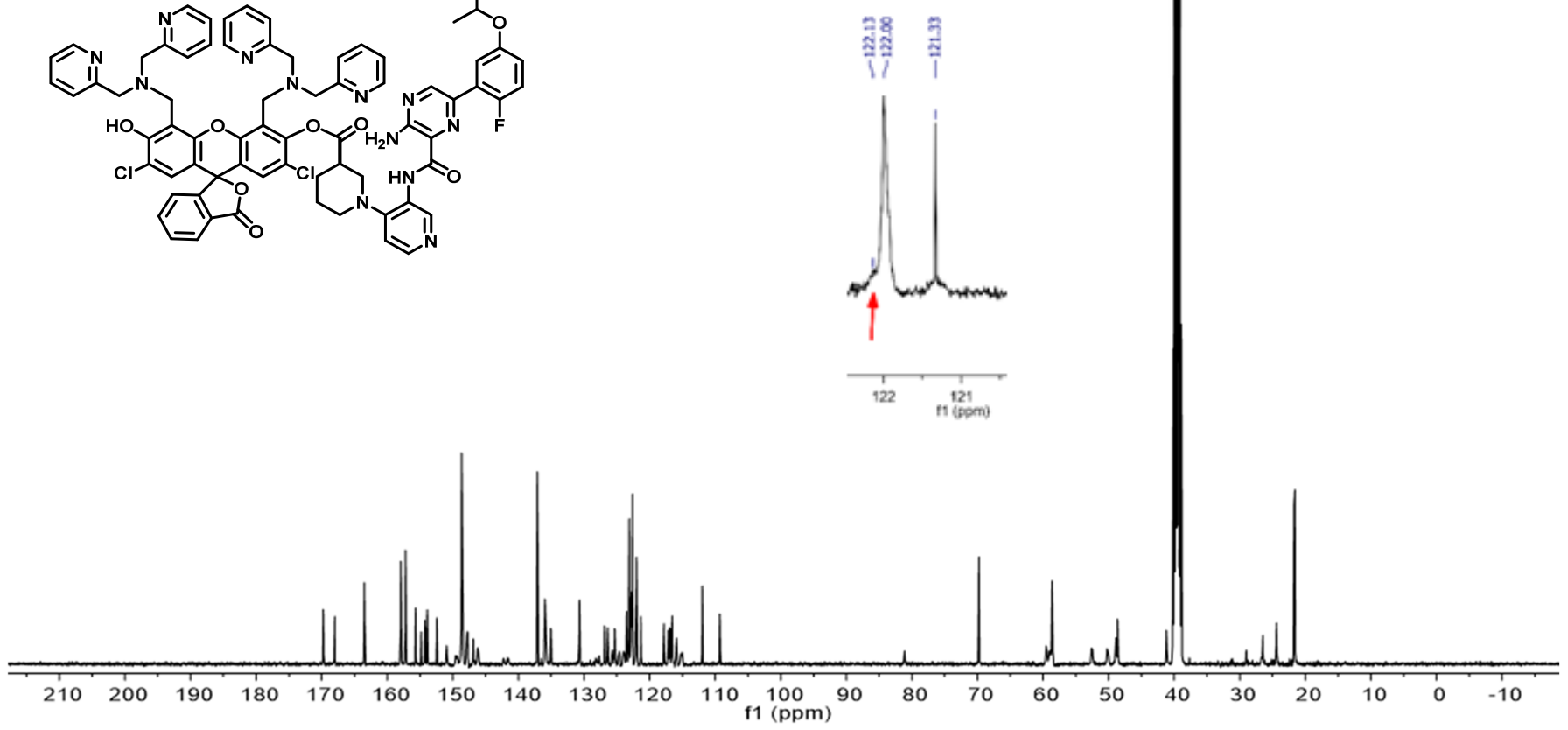

Figure S21. ${ }^{13} \mathrm{C}$ NMR spectrum of ZnPD5. 


\section{ZnPD5 LCMS Trace}
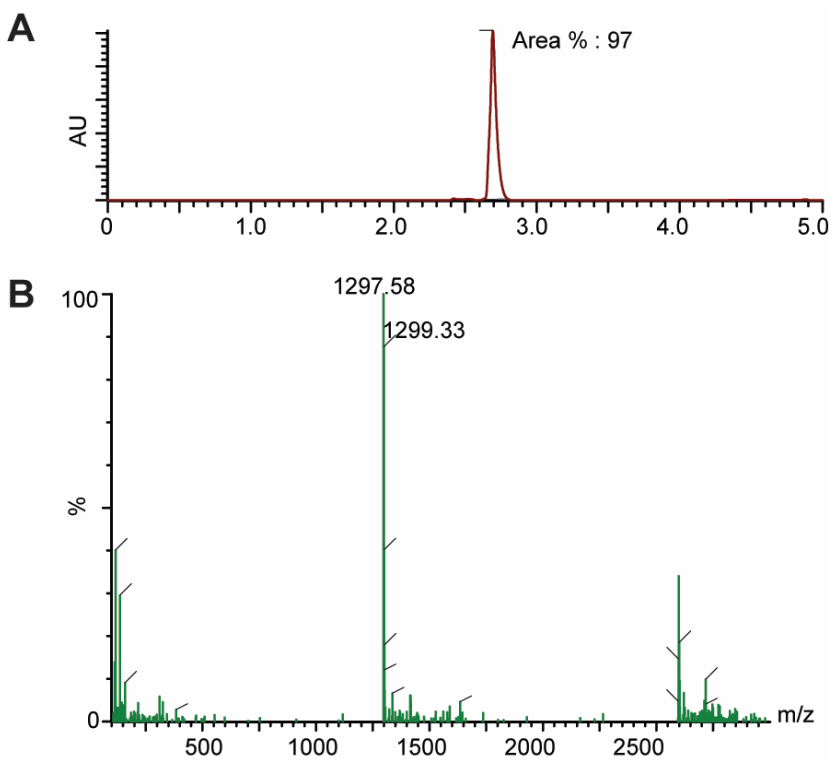

Figure S22. (A) LCMS UV (254 nm) trace for ZnPD5 (B) Observed mass of ZnPD5. 